\title{
A STANDARDS-BASED THEORY OF JUdicial REVIEW AND THE RULE OF LAW
}

\author{
Richard E. Levy ${ }^{*}$ \\ Sidney A. Shapiro ${ }^{* *}$
}

Virtually everyone in today's society is the recipient of some kind of government benefit, whether in the form of government employment or contracts, licenses or permits, or direct monetary or in-kind benefits. ${ }^{1}$ Notwithstanding the prevalence and importance of government benefits, the Supreme Court has apparently taken the position that, when it comes to the administration of government benefits, the availability of judicial review by an Article III judge is contingent on legislative discretion. If Congress chooses to preclude or limit this fundamental rule of law safeguard, the Court has given every indication that it is willing to go along.

The constitutionality of legislative preclusion of judicial review has received considerable attention from constitutional and administrative law scholars. ${ }^{2}$ In fact, it is the subject of one of the longest running and most contentious debates in the federal courts scholarship. ${ }^{3}$ Academic commentary on the issue varies widely, ranging from the position that

\footnotetext{
* Professor of Law, University of Kansas.

** University Distinguished Chair in Law, Wake Forest University.
}

The authors would like to thank Professors Charles Koch, Richard Fallon and Ronald Levin for their helpful comments. We would also like to thank faculty members at the Wake Forest Law School, the University of Cincinnati Law School, and the University of Colorado School of Law for their helpful input on earlier versions of this article during faculty workshops.

${ }^{1}$ We use the term "government benefits" to describe a broad spectrum of benefits, including welfare and social security, public employment and government contracts, and occupational licenses or building permits. Their common feature is that they are benefits (including in principle relief from costs or burdens) that private persons receive from the government. We have chosen the term government benefits carefully to avoid the confusing doctrinal connotations of the Article III concept of "public rights." See infra notes _ and accompanying text (discussing public rights). Nonetheless, as we use the concept of government benefits, these interests would typically be regarded as public rights.

${ }^{2}$ See infra notes ___ \& accompanying text.

${ }^{3}$ See infra notes __ \& accompanying text. 
Congress can freely preclude Article III review to the position that Congress must provide for such review, with other scholars taking intermediate positions that allow Congress to preclude judicial review of some issues, but not others.

We join this debate by proposing a new approach: a standards-based theory of judicial review. The standards-based approach supports a much broader right to judicial review that would encompass most administrative decisions, including decisions concerning government benefits. We are not the first scholars to argue that the Constitution requires Article III review of government benefit decisions (or other agency action), but the standards-based approach offers a novel and, we believe, more coherent and workable approach to these fundamental constitutional issues.

Our standards-based theory is based on two fundamental principles. First, whenever government officials make decisions involving the application of legal standards, the rule of law - and hence the rule of law safeguards of due process and judicial review - attach. Second, with the exception of those cases in which the Constitution itself contemplates standardless official discretion, legislative delegations of authority to government actors must contain legal standards that guide and control discretion. Because the availability of judicial review is tied to the existence of standards and standards are in most instances constitutionally required, the standards-based approach ensures that Article III judicial review of administrative action is broadly available to promote agency compliance with the rule of law.

This article is part of a larger project to rethink the application of core rule of law safeguards to government benefits. In a previous article, ${ }^{4}$ we criticized the Court's current entitlement approach to procedural due process in government benefit cases. That approach leaves essential procedural safeguards, including notice and the right to be heard, contingent on legislative discretion. We argued that the current approach is the product of historical misunderstandings and doctrinal missteps, and we advanced the standards-based approach to the rule of law as a means of bringing coherence to due process doctrine and securing due process protections for government benefits. Judicial

${ }^{4}$ We have addressed the failures of the Court's procedural due process jurisprudence as it applies to government benefits in a related article. See Sidney A. Shapiro \& Richard E. Levy, Government Benefits and the Rule of Law: Toward a Standards-Based Theory of Due Process, 57 ADMIN. L. REV.107 (2005). 


\section{STANDARDS-BASED JUDICIAL REVIEW}

3

review of government benefits, like due process, is plagued by doctrinal incoherence that ultimately permits Congress to curtail or dispense with this essential rule of law safeguard.

Our aim is to restore judicial review to its rightful place in ensuring the rule of law is followed in the allocation of government benefits. We say "restore" because Marbury v. Madison, the seminal opinion concerning the rule of law, indicates that Article III review of the government benefit decisions of the Executive Branch is constitutionally compelled. ${ }^{6}$ The Court's seminal pronouncements concerning the rule of law were articulated in the context of a government benefit - Marbury's claim to government employment.

Our analysis proceeds in several steps. Part I of the article examines Chief Justice Marshall's opinion in Marbury v. Madison, which, as mentioned, indicates that Article III review of the government benefit decisions is constitutionally compelled. This aspect of Marbury has been overlooked by other scholars and by the Supreme Court, which has failed to account for it in its preclusion decisions.

Part II analyzes the "public rights" doctrine. Under current interpretations of the public rights doctrine, Congress may freely delegate the adjudication of government benefits to an administrative agency (or other non-Article III forum) and foreclose judicial review of those decisions by Article III judges. ${ }^{7}$ We reexamine the case law that has given rise to this interpretation and reach a different conclusion. While the doctrine justifies the first-instance adjudication of facts and law by the Executive Branch, it does not, and cannot, justify legislative preclusion of judicial review of such decisions.

Part III examines the Supreme Court's decisions addressing legislative preclusion of judicial review by Article III judges, which

\footnotetext{
${ }^{5} 5$ U.S. (1 Cranch) 137 (1803).

${ }^{6}$ Recent scholarship has cast doubt on the historical significance of Marbury, suggesting that the case had little influence throughout most of the Nineteenth Century, and was "rediscovered" during the Lochner era in order to justify judicial activism on behalf of economic rights. See, e.g, LARRY KRAMER, THE PEOPle ThEMSElves: Popular CONSTITUTIONALISM AND JUdiCIAL REVIEW (2004). Whatever the accuracy of these historical accounts, Marbury's rule of law analysis remains foundational for current constitutional doctrine. More fundamentally, the rule of law premises of Marbury have not been drawn into question.

${ }^{7}$ See infra notes _ \& accompanying text.
} 
seem to suggest that preclusion in ordinary cases does not violate either due process or Article III absent an independent constitutional violation. The precise basis and contours of this doctrine, however, remain muddled at best. More fundamentally, this result seems to us irreconcilable with the rule of law. Thus, our examination of the case law in these areas leads us to the conclusion that the standards-based approach offers a superior foundation for analyzing the preclusion of review.

Finally, part IV elaborates on our standards-based approach to judicial review and explains how it impacts several issues that arise in conjunction with legislative preclusion of review. We also compare our approach to the large and contentious literature on legislative preclusion of judicial review. We identify others who agree with us that Congress cannot generally preclude judicial review and argue why our approach is preferable to the approach taken by these other commentators. We end Part IV by contrasting two government benefit systems: the Social Security disability system, which is subject to meaningful review by Article III courts, and the Veterans Benefit system, which is not. We explain why experience with these two systems supports our contention that Article III judicial review is an essential element in the protection of rule of law.

\section{MARBURY V. MADISON}

We begin with the premise that the rule of law, as a matter of constitutional principle and sound policy, should apply to government benefit decisions. Decisions concerning government benefits are subject to statutory standards in most cases, and under the rule of law those standards bind government officials. Because the constitutional functions of due process and separation of powers can and should be understood as providing essential safeguards to ensure compliance with statutory standards, ${ }^{8}$ judicial review should apply to benefit decisions.

While the rule of law has various connotations and shades of meaning, at bottom it reflects a core requirement of legal regularity under which government actors derive their authority from and are bound by the law. ${ }^{9}$ The seminal rule of law decision for American constitutional jurisprudence, Marbury v. Madison, articulated and applied fundamental rule of law principles in the context of a

\footnotetext{
${ }^{8}$ See infra notes ___ \& accompanying text.

9 See generally Richard Fallon, Jr., "The Rule of Law” as a Concept in Constitutional Discourse, 97 COLUM. L. REV. 1 (1997).
} 


\section{STANDARDS-BASED JUDICIAL REVIEW}

5

government benefit: William Marbury's claim to a commission as a federal Justice of the Peace, which Secretary of State James Madison refused to deliver after taking office. ${ }^{10}$ It follows that the differences between government benefits and private rights do not justify their exclusion from essential rule of law safeguards.

The Court held that while Marbury was entitled to a writ of mandamus to remedy Madison's wrongful refusal to deliver his commission, ${ }^{11}$ Congress could not constitutionally confer original jurisdiction on the Supreme Court to issue the writ. ${ }^{12}$ The latter proposition was the occasion for Marshall's famous assertion of judicial authority to declare legislative acts unconstitutional, but Marshall also relied on rule of law principles to conclude that Marbury was entitled to a writ of mandamus, which is the part of the opinion that establishes the basic rule of law framework for administrative action.

Chief Justice Marshall supported his conclusion that Marbury was entitled to a remedy for Madison's failure to deliver his commission with a negative proof premised on core rule of law principles. ${ }^{13}$ The first

10 The plaintiff, William Marbury, had been appointed under Midnight Judge's Act of 1801, a last-ditch effort by the Federalists (who had lost the last election) to ensconce themselves in power by creating and filling new judicial and executive offices. Marbury's commission had been signed and sealed, but John Marshall himself, who at the time was serving as Secretary of State, neglected to ensure its delivery before leaving office. His successor as Secretary of State, James Madison, refused to deliver it. For extended discussions of Marby in historical context, see James O'Fallon, Marbury, 44 StAN. L. REV. 219 (1992); William Van Allstyne, A Critical Guide to Marbury v. Madison, 1969 DUKE L. J. 1

${ }^{11} 5$ U.S. (1 Cranch) at 163-73. As a threshold matter, the Chief Justice initially concluded that Marbury's right to the commission had vested when signed and sealed, even though it had not been delivered. Id. at 155-62. Although this conclusion may have been incorrect as a matter of then prevailing law (and perhaps tainted by a conflict of interest, insofar as it was Marshall himself who had failed to deliver the commission), these questions do not undermine the rule of law reasoning that followed.

${ }^{12} I d$. at 173-80. As we develop later in the article, we believe this conclusion was based on a misreading of Article III's provisions allocating original and appellate jurisdiction. See infra notes __ and accompanying text. Our disagreement with Chief Justice Marshall on this point does not affect the force of the basic rule of law principles he articulated.

13 Marshall's decision to strike down the statute conferring original jurisdiction to the Supreme Court to issue writs of mandamus as inconsistent with Article III was likewise premised on rule of law principles. This conclusion was based on the premise that Article III's list of cases within the original 
proposition of this proof was that under the rule of law, there is a legal remedy for the wrongful denial of a right. ${ }^{14}$ As Marshall put it, "[t]he very essence of civil liberty certainly consists in the right of every individual to claim the protection of the laws, whenever he receives an injury." 15 The second proposition is that the Constitution established a rule of law state, expressed in Marshall's famous pronouncement that ours is a government of laws, not men. ${ }^{16}$ Marshall then reasoned to a contradiction: "It will certainly cease to deserve this high appellation, if the laws furnish no remedy for the violation of a vested legal right."17 This contradiction proved the opposite: that the laws must provide a remedy for the wrongful denial of the commission. Marshall took it as a given that the remedy to be provided would be a judicial one, presumably because it is "profoundly the province of the judiciary to say what the law is." 18

In making these pronouncements, Chief Justice Marshall was not troubled in the least by the fact that the right at issue - Marbury's commission - was a governmentally created interest. ${ }^{19}$ Indeed, at

jurisdiction of the Supreme Court is an exclusive one. See id. at 174-75. While we disagree with this premise, see infra notes __ and accompanying text, that does not refute the rule of law reasoning on which judicial review is based For Chief Justice Marshall, the adoption of a written constitution in which the powers of government are limited necessarily implied that the constitution was fundamental or superior law. See id. at 176-77. As such, when courts were called upon to resolve cases and controversies, their duty was to apply the superior law - i.e., the Constitution. See id. at 177-80.

${ }^{14} I d$. at 163. Marshall supported this premise by reference to Blackstone's statement that "where there is a legal right, there is also a legal remedy by suit or action at law whenever that right is invaded." Id. (quoting Blackstone's Commentaries, Volume 3, at 23).

${ }^{15} I d$.

${ }^{16} I d$. (quoted supra text at note___ ).

${ }^{17} I d$.

${ }^{18}$ Id. at 177. Although Marshall made this latter point in connection with his discussion of judicial review of legislation, see infra notes __ and accompanying text, it would seem to be equally applicable to judicial review of executive action. Under the United States constitutional system, the judiciary bears the final responsibility for determining the legality of governmental action, and for this reason we regard judicial review as an essential rule of law safeguard. See infra notes __ and accompanying text. In other constitutional systems, alternative mechanisms for ensuring the legality of government action might be fully consistent with the rule of law.

${ }^{19} \mathrm{He}$ simply assumed that "if [Marbury] has been appointed, the law continues him in office for five years, and he is entitled to the possession of those evidences of office, which, being completed, became his property." 5 U.S. 


\section{STANDARDS-BASED JUDICIAL REVIEW}

7

various points in the opinion Marshall cited other examples involving government benefits, including veterans' pensions ${ }^{20}$ and patents for public land, ${ }^{21}$ as obvious cases in which the rule of law required a remedy for wrongful government action.

Nor did it trouble Marshall that the right was being asserted against the government, insofar as he rejected any exception from a writ of mandamus based on Madison's high office. ${ }^{22}$ More directly, in an oftenoverlooked passage, Marshall rejected any suggestion that sovereign immunity would prevent legal remedies against government officials who act in violation of their legal duties. ${ }^{23}$

Likewise, we see no reason why decisions about government benefits should be any less protected by the rule of law than governmental decisions affecting private property. The violation of the rule of law is no less when the government fails to follow statutory standards in the determination of government benefits than when it commits the same sin in decisions that adversely affect private property. While there are differences between private property and government

(1 Cranch) at 155; see also id. at 162 ("To withhold his commission, therefore, is an act deemed by the court not warranted by law, but violative of a vested legal right."). While Marshall spoke of the "evidences" of office as the property in question, this was merely a convenient fiction. It is clear from his treatment of the issue in other contexts that the underlying right to serve in the office was at issue. See id. at 173 (concluding that there is no alternative legal remedy so as to render mandamus inappropriate because " $[\mathrm{t}]$ he value of a public office not to be sold, is incapable of being ascertained; and the applicant has a right to the office itself, or nothing.").

${ }^{20}$ See id at 164:

By the act concerning invalids, passed in June 1794, the secretary at war is directed to place on the pension list all persons whose names are contained in a report previously made by him to congress. If he should refuse to do so, would the veteran be without a remedy? Is it to be contended that where the law in precise terms directs the performance of an act in which an individual is interested, the law is incapable of securing obedience to its mandate?

${ }^{21}$ See id. at 171 (citing the failure "to record a commission, or a patent for land" as examples of cases in which "it is not perceived on what ground the courts of the country are further excused from the duty of giving judgment, that right to be done an injured individual, than if the same services were to be performed by a person not the head of a department.") While land may be viewed as traditional private property, a patent for land is a government benefit in the sense that the government creates an individual interest in formerly public lands.

${ }^{22} I d$. at 169-73.

${ }^{23} \mathrm{Id}$. at 165 . 
benefits that might justify a greater level of substantive protection for the creation and retention of private wealth, ${ }^{24}$ the injury to rule of law principles is the same regardless of the character of the underlying interest.

In sum, the rule of law principles articulated in Marbury, including the right of judicial review of executive action for compliance with the law, were articulated in the context of a government benefit case and must be regarded as fully applicable to government benefits. Marbury does not recognize either the governmental creation of these interests or their assertion as rights against the government as having any implications for the rule of law. ${ }^{25}$ This makes sense because the government's failure to comply with statutory standards is a violation of the rule of law whether it involves government benefits or private property.

Despite Marbury, however, the Supreme Court and many commentators have generally assumed that judicial review of the factual and legal basis for ordinary government benefit claims may be statutorily precluded. One basis for this assumption is the public rights doctrine, which we consider in the following section.

\section{The Public Rights Doctrine}

The "public rights" doctrine figures prominently in cases analyzing whether administrative adjudication infringes on judicial power in violation of Article III. Under modern case law, as we will develop, ${ }^{26}$ public rights encompass all forms of government benefits. Although the cases discussing the doctrine involve only the propriety of first instance administrative adjudication, the Court's broad pronouncements imply that Congress may assign adjudication of public rights to administrative agencies with no judicial review. As we demonstrate in this part of the Article, however, the public rights doctrine, properly understood, is simply irrelevant to the question of judicial review.

\section{A. Historical OVerview}

\footnotetext{
${ }^{24}$ For an elaboration of this point, see Shapiro \& Levy, supra note __, at $145-46$.

${ }^{25}$ As we take up in Part II, the Court has sometimes premised its "public rights" doctrine on the government's sovereign immunity, which is understood to authorize Congress to preclude Article III judicial review of government benefit decisions.

${ }^{26}$ See infra notes ___ and accompanying text (discussing Granfinanciera).
} 


\section{STANDARDS-BASED JUDICIAL REVIEW}

9

The public rights doctrine originated in Murray's Lessee v. Hoboken Land and Improvement Company, ${ }^{27}$ a mid-nineteenth century decision, in which the Court stated broadly that "there are matters, involving public rights, which may be presented in such form that the judicial power is capable of acting on them, and which are susceptible of judicial determination, but which congress may or may not bring within the cognizance of the courts of the United States, as it may deem proper." ${ }^{28}$ With the rise of the administrative state, Murray's Lessee took on a talismanic importance for the reconciliation of administrative adjudication with Article III. The Court has relied on the distinction between public and private rights in a series of decisions deciding the constitutionality of administrative adjudication. ${ }^{29}$ These cases have raised more questions about the public rights doctrine than they have resolved, leaving the doctrine in an incoherent muddle.

\section{CROWELL V. BENSON}

One of the first landmark cases for modern administrative adjudication, Crowell v. Benson, ${ }^{30}$ upheld the first-instance adjudication of a workers compensation claim by an administrative tribunal. The Court began its analysis with the distinction between public and private rights, stating in dicta that the "mode of determining [public rights] is completely within congressional control.",31 The public rights doctrine

${ }^{27} 59$ U.S. (18 How.) 272 (1855).

${ }^{28} \mathrm{Id}$. at 284.

29 The public rights doctrine has also been used to uphold the creation of "legislative" or "Article I" courts whose judges do not meet Article III requirements, such as the Tax Court and the Court of Claims. See generally Fallon, supra note __, at 921-23. For purposes of our analysis, these tribunals are no different than administrative agencies performing judicial functions.

30285 U.S. 22 (1932). There were a number of cases invoking the doctrine between Murray's Lessee and Crowell, see id. at 50-51 (citing cases), but Crowell is usually regarded by both courts and commentators as laying the foundations for modern administrative adjudication.

${ }^{31}$ Id. at 50 (quoting Ex parte Bakelite Corp., 279 U.S. 438, 451 (1929)). Bakelite upheld the Court of Claims as a legislative court, identifying such claims as falling in the class of cases "arising between the government and others, which from their nature do not require judicial determination and yet are susceptible of it." Id. Bakelite expressly relied on sovereign immunity, noting that

Conspicuous among such matters are claims against the United States. These may arise in many ways and may be for money, lands, or other things. They all admit of legislative or executive determination, and yet from their nature are susceptible of determination by courts; but no 
was inapplicable in Crowell, however, because the case arose between private parties and therefore concerned a matter of private rights. ${ }^{32}$

The Court nonetheless upheld adjudication of the claim by an administrative tribunal, approving its role as an "adjunct" to the courts. ${ }^{33}$ Critically, and in contrast to the Court's assumptions regarding public rights, under the adjunct theory, the use of agencies to determine private rights was permissible only if there was judicial review, which had to be de novo as to questions of law and as to questions constitutional or jurisdictional fact. ${ }^{34}$ While the requirements of de novo review have faded, ${ }^{35}$ the basic dichotomy articulated by Crowell continues to influence the analysis of administrative adjudication: administrative adjudication of public rights is apparently permissible without any judicial review, while administrative adjudication of private rights is permissible only if the Courts retain sufficient power of review.

\section{NORTHERN PIPELINE CO.}

The uncertainty of the rationale for public rights was explicitly noted in the next major decision invoking the doctrine, Northern Pipeline Co. v. Marathon Pipe Line Co., ${ }^{36}$ which invalidated provisions of the Bankruptcy Code conferring on bankruptcy courts broad jurisdiction over common law claims involving a debtor's estate. In his plurality opinion in Northern Pipeline, Justice Brennan distinguished bankruptcy court adjudication of common law claims from other accepted categories of legislative courts, including those adjudicating of public rights.

court can have cognizance of them except as Congress makes specific provision therefor. Nor do claimants have any right to sue on them unless Congress consents; and Congress may attach to its consent such conditions as it deems proper, even to requiring that the suits be brought in a legislative court specially created to consider them.

$I d$. at 452. Congress subsequently proclaimed that the Court of Claims (as well as the Patent Court) was an Article III court and the reasoning of Bakelite has been drawn into question by the Supreme Court. See Glidden Co. v. Zdanok, 370 U.S. 530, 531, 547-49 (1962).

32285 U.S. at 51.

${ }^{33}$ Id. at 51-52. The Court analogized the agency to the use of special masters to find facts.

${ }^{34}$ See 285 U.S. at 51-61. The Court then construed the statute to permit such review (so as to avoid constitutional difficulty) and approved the trial court's de novo determination that the agency lacked jurisdiction.

35 See, e.g., Richard J. Pierce, Jr., Sidney A. Shapiro \& PaUl R. VERKUIL, ADMINISTRATIVE LAW AND PROCESS $§$ 5.2.2. (3d ed. 1999).

${ }^{36} 458$ U.S. 50 (1982). 


\section{STANDARDS-BASED JUDICIAL REVIEW}

11

After quoting from Murray's Lessee, the plurality opinion noted two rationales for the public rights doctrine:

This doctrine may be explained in part by reference to the traditional principle of sovereign immunity, which recognizes that the Government may attach conditions to its consent to be sued. ... . But the public-rights doctrine also draws upon the principle of separation of powers, and a historical understanding that certain prerogatives are reserved to the political Branches of Government. $^{37}$

Justice Brennan found it unnecessary to define public rights with great precision because "at a minimum" they only arise when the government is a party, which was not the case in the context of the bankruptcy adjudication in question. ${ }^{38}$ Having determined that the bankruptcy courts did not fall within the public rights or any other legislative court exception to Article III, Justice Brennan ultimately concluded that the bankruptcy courts' broad jurisdiction was unconstitutional because it transferred the "essential attributes of judicial power" to non-Article III courts. $^{39}$

\section{THOMAS V. UNION CARBIDE}

In Thomas v. Union Carbide, ${ }^{40}$ the Court moved away from a categorical distinction between public and private rights. Thomas is significant because it arose between private parties, yet Justice O'Connor, writing for the majority, noted that the right at issue "bears many of the characteristics of a public right" because it involved "an agency administering a complex regulatory scheme." ${ }^{11}$ The right was a statutory right of an initial pesticide registrant to be compensated by a follow-on registrant, who was permitted to rely on data submitted by the initial registrant after paying the initial registrant for use of the data. If the initial and follow-on registrants could not agree on reasonable compensation, the statute provided for mandatory and binding

${ }^{37}$ Id. at 67 (citations to Murray's Lessee and Ex parte Bakelite omitted).

${ }^{38}$ Id. at 69 . Justice Brennan's discussion also indicated that public rights arise only with respect to matters that "could have been determined exclusively" by the legislative or executive branch. Id. at 68. This view of the doctrine is quite narrow, and we would agree with it insofar as foreclosure of judicial review is concerned. See infra notes and accompanying text.

${ }^{39}$ See id. at $84-85$.

40473 U.S. 568, 585-86 (1985).

${ }^{41} 473$ U.S. at 589. 
arbitration, with very limited judicial review. Although the arbitration mechanism at issue in Thomas permitted review only for fraud, misconduct, or misrepresentation and for constitutional errors, the Court upheld this provision because it preserved the "'appropriate exercise of the judicial function."” 42

In light of the relationship between the statutory scheme and the private rights, Justice O'Connor concluded that "Congress, acting for a valid legislative purpose pursuant to its constitutional powers under Article I, may create a seemingly 'private' right that is so closely integrated into a public regulatory scheme as to be a matter appropriate for agency resolution with limited involvement by the Article III judiciary." ${ }^{43}$ Based on this language, it is unclear whether the Court concluded that the right was a public right or merely that, although it was a private right, its public rights features justified administrative adjudication. Critically, however, by reference to the public rights doctrine, the Court upheld determination of claims by a non-Article III tribunal with only very limited judicial review. ${ }^{44}$

\section{CFTC V. SCHOR}

The next case, CFTC v. Schor, ${ }^{45}$ is more significant than Thomas because it purported to adopt a new and comprehensive test for administrative adjudication. Schor upheld the adjudication by the CFTC of state common law contract claims asserted by the defendant brokerage firm in response to the plaintiff customer's private claims alleging violations of the federal commodities laws. ${ }^{46}$

In analyzing the Article III issue, the opinion articulated and applied a three factor test which considers:

the extent to which the "essential attributes of judicial power" are reserved to Article III courts, and, conversely, the extent to which the non-Article III forum exercises the range of jurisdiction and powers normally vested only in Article III courts, the origins and importance of the right to be adjudicated, and the concerns that drove Congress to depart from the

${ }^{42} i d$. at 592.

${ }^{43} I d$. at 593-94.

${ }^{44}$ As we will explain further in later portions of this article, review for fraud, misconduct, misrepresentation, and constitutional error are insufficient to preserve the rule of law. See infra notes

${ }^{45} 478$ U.S. 833 (1986).

${ }^{46} 478$ U.S. at 851. 


\section{STANDARDS-BASED JUDICIAL REVIEW}

13

requirements of Article III. ${ }^{47}$

Within the context of this test, the majority expressly rejected the Marathon plurality's categorical treatment of the public rights doctrine, which became only a factor to be considered within the context of the "origins and importance of the right to be adjudicated" component of the test. $^{48}$

Under the first component of Schor test, the scope of judicial review is a critical factor in determining whether the essential attributes of judicial power have been reserved to Article III courts. Thus, unlike the cases before it, Schor implies that Article III may require judicial review of administrative adjudications involving public rights. At the same time, however, because the origins and importance of the right asserted is also a factor, the Schor test apparently continues to accord public rights second class status and implies that a narrow scope of review, such as that in Thomas, would be constitutional when public rights are involved.

Schor's treatment of the public rights doctrine focused on the executive power rationale for administrative adjudication. Both it and Thomas observed that "the public rights doctrine reflects simply a pragmatic understanding that when Congress selects a quasi-judicial method of resolving matters that 'could be conclusively determined by the Executive and Legislative Branches', the danger of encroaching on the judicial powers' is less ...." "49 Conversely, neither Schor nor Thomas mentioned sovereign immunity or congressional consent as a factor. ${ }^{50}$

${ }^{47}$ Id. The essential attributes factors was itself to be evaluated in light of various considerations, including the breadth of jurisdiction vested in the nonArticle III tribunal, the scope of judicial review, and the ancillary judicial powers vested in the non-Article III tribunal. See id. at 851-53.

48 See id. at 853. ("[T]his Court has rejected any attempt to make determinative for Article III purposes the distinction between public and private rights ....") (citing Thomas).

${ }^{49}$ Id. at 853-54 (quoting Thomas at 589 (quoting Marathon at 68)).

${ }^{50}$ Under the Schor test, the scope of judicial review of public rights is only a factor in assessing the constitutionality of administrative adjudication of public rights. On the other hand, judicial scrutiny of administrative adjudication of public rights would apparently be less "searching" than what appears already to be a very loose test for private rights. See id. at 854. This point was explicit in Thomas, where Justice O'Connor observed that a majority of the Court did not "endorse the implication of the private right/public right dichotomy that Article III has no force simply because a dispute is between the Government and an individual." 473 U.S. at 586 (citing Northern Pipeline, 458 U.S. at 68 n.20 and 


\section{GRANFINANCIERA}

Schor seemed to bring some order to this area by crafting a comprehensive, if open-ended, test. This clarity, however, was shortlived because of the Court's decision in Granfinanciera, S.A. v. Nordberg, ${ }^{51}$ decided only three years later. Granfinanciera was a Seventh Amendment case challenging the constitutionality of bankruptcy court jurisdiction to adjudicate preferential transfer claims without a jury. The Court's opinion, written by Justice Brennan (who also authored the Marathon plurality), expressly incorporated the Article III public rights doctrine into its Seventh Amendment analysis. ${ }^{52}$

Without addressing the availability of judicial review, Justice Brennan returned to the more categorical assumption that public rights could be freely assigned to administrative adjudication without violating the Seventh Amendment or, by extension, Article III. ${ }^{53}$ The Court then further confused existing doctrine by adopting an expanded definition of public rights, which would include "'a seemingly 'private' right that is so closely integrated into a public regulatory scheme as to be a matter appropriate for agency resolution with limited involvement by the Article III judiciary.",54

70 n.23).

${ }^{51} 492$ U.S. 33 (1989).

${ }^{52} \mathrm{Id}$. at 53:

Indeed, our decisions point to the conclusion that, if a statutory cause of action is legal in nature, the question of whether the Seventh Amendment permits Congress to assign its adjudication to a tribunal that does not employ juries as factfinders requires the same answer as whether Article III allows Congress to assign adjudication of that cause of action to a non-Article III tribunal. For if a statutory cause of action . . . is not a 'public right' for Article III purposes, then Congress may not assign its adjudication to a specialized non-Article III court . . . . And if the action must be tried under the auspices of an Article III court, then the Seventh Amendment affords the parties a right to a jury trial whenever the cause of action is legal in nature.

${ }^{53}$ See id. at 51 ("Congress may devise novel causes of action involving public rights free from the strictures of the Seventh Amendment if it assigns their adjudication to tribunals without statutory authority to employ juries as factfinders.").

${ }^{54}$ Id. at 54 (quoting Thomas, 473 U.S. at 593-94). The Court also cited Thomas as rejecting the view that "'a matter of public rights must at a minimum arise 'between the government and others."' Id. (quoting Justice Brennan's Marathon plurality, 458 U.S. at 69, which in turn quoted Ex parte Bakelite, 279 U.S. at 451). Even applying the broader definition of public rights, the majority 


\section{STANDARDS-BASED JUDICIAL REVIEW}

15

Although Granfinanciera did not attempt to explain the public rights doctrine, it seemed to focus on administrative adjudication as execution of the law. ${ }^{55}$ Since the Court anticipated that some rights arising between private parties could be the public rights, it is inconsistent with the sovereign immunity rationale for public rights on which the Court had previously relied. In any case, the analysis also returns to the categorical approach to the public rights doctrine, which - taken together with the new, broader definition of public rights - threatens to undermine judicial review as a rule of law safeguard for some private rights. Thus, for example, Professors Aman and Mayton caution that under Granfinanciera, "almost any private, common-law sort of action may be converted by Congress to a matter of public right and thereby moved outside the zone of Article III courts."

The majority's reasoning provoked a concurring opinion from Justice Scalia, who flatly rejected the expanded definition of public rights and emphasized the sovereign immunity rationale from Murray's Lessee. $^{57}$ After an extensive discussion of Murray's Lessee, Justice Scalia continued:

It is clear that what we meant by public rights were not rights important to the public, or rights created by the public, but rights of the public - that is, rights pertaining to claims brought by or against the United States. For central to our reasoning was the device of waiver of sovereign immunity, as a means of converting a subject which, though its resolution involved a "judicial act," could not be brought before the courts, into the stuff of an Article III "judicial controversy." Waiver of sovereign immunity can only be implicated, of course, in suits where the government is a party. ${ }^{58}$

Justice Scalia disagreed not only with the expansion of public rights

concluded that a fraudulent conveyance action in bankruptcy was not a public right and invalidated the adjudication of such claims without a jury.

${ }^{55}$ See id. at 51-55.

56 Alfred C. Aman, JR. \& William T. Mayton, Administrative LaW $122\left(1^{\text {st }}\right.$ ed 1993).

${ }^{57}$ See 492 U.S. at 65-71.

${ }^{58} \mathrm{Id}$. at 68 (emphasis in original). As will be developed infra notes ___ and accompanying text, we agree with Justice Scalia that public rights refer to rights of the public, but not with his conclusion that this understanding implicates sovereign immunity. 
doctrine to include some rights between private parties, but also with the open-ended analysis of Schor, and he would apparently envision a very strict limitation on non-Article III adjudication of private rights between parties. $^{59}$

\section{B. DOCTRINAL INCOHERENCE}

We think that few will disagree with our conclusion that the public rights doctrine is a mess. Several critical questions remain unresolved. First, the doctrine's underlying rationale remains unclear. Second, it is unclear whether the presence of a public right categorically removes the case from Article III requirements, or whether it is simply a factor to be considered. Finally, it is unclear the extent to which rights arising between private parties may be characterized as public rights and why this would be so. More fundamentally, however, to the extent that the doctrine implies that Congress may preclude or sharply limit judicial review of administrative decisions, it is inconsistent with Marbury and the rule of law.

The cases identify two distinct rationales without clearly articulating either. Traditional accounts of the doctrine emphasize sovereign immunity and reason that because Congress need not grant any remedy against the government, there can be not objection to the provision of an administrative remedy without judicial review. ${ }^{60}$ Consider, for example, the following hornbook explanation of Murray's Lessee:

The Court [in Murray's Lessee] explained that Article III does not apply to public rights because of the doctrine of sovereign immunity. Since the federal government may not be sued without its consent, a litigant is entitled to sue in federal court claiming rights created by an act of Congress only if that or another law consents to such suit. ${ }^{61}$

The sovereign immunity rationale is not entirely satisfying for a number of reasons. This sort of greater-includes-the-lesser-power inclusion has been rejected in other contexts, such as procedural due process, where the greater power to create an entitlement does not

${ }^{59}$ See id. at 69-71.

${ }^{60} \mathrm{See}$, e.g., Michael Asimow, ARThUR EARL Bonfield \& RONALD M. LEVIN, STATE AND FEDERAL ADMINISTRATIVE LAW 636 (1998) ("The consensus of the commentators is that Congress can deprive the federal courts of the power to review some disputes (such as claims for Medicare benefits), but cannot deny litigants a federal forum for the assertion of constitutional claims.").

${ }^{61}$ PIERCE, ShapIRo \& VerkUIL, supra note___, at 75. 


\section{STANDARDS-BASED JUDICIAL REVIEW}

17

include the lesser power to specify the procedures attached to its termination. ${ }^{62}$ Even accepting its logic, the argument rests on the faulty premise that sovereign immunity would bar any form of judicial remedy against the government. This is simply wrong; under the doctrine of Ex Parte Young, ${ }^{63}$ sovereign immunity does not prevent suits against government officials for injunctive relief to prevent illegal conduct. ${ }^{64}$ Indeed, the sovereign immunity rationale is directly contrary to Marbury's treatment of sovereign immunity. ${ }^{65}$

The executive power rationale for the public rights doctrine, which was emphasized in Northern Pipeline, appears to be on the ascendancy. ${ }^{66}$ Nonetheless, this rationale remains entirely unexplained. The Court has stated that administrative determinations resembling judicial decisions have elements of executive power when public rights are involved, ${ }^{67}$ but never explained why. Instead, this explanation is entirely circular: administrative adjudication of public rights is permissible because such determinations are executive in character, and they are executive in character because they are public rights. Characterizing public rights decisions as executive, moreover, does not explain why judicial review can be foreclosed or sharply limited. Marbury posits precisely the opposite - that there must be a remedy for unlawful executive action.

The underlying confusion about the rationale for the public rights doctrine breeds confusion about its application. This uncertainty affects the very definition of public rights. Granfinanciera's extension of public rights to some congressionally created rights between private parties removed the bright line certainty of the traditional understanding of Crowell v. Benson and Northern Pipeline that public rights arise only when the government is a party. Interpreted broadly, this definition could convert many seemingly private rights - including the workers

62 See Shapiro \& Levy, supra note at 118 (discussing the Court's rejection of this argument). The Court's treatment of government benefits in the due process context is closely connected to the question of judicial review, because procedural due process and judicial review are the two principal rule of law safeguards built into the constitutional order.

63209 U.S. 123 (1908).

${ }^{64}$ See, e.g., Alden v. Maine, 527 U.S. 706 (1999).

65 See supra note ___ and accompanying text (discussing often overlooked passage in Marbury that rejects sovereign immunity as a bar to a remedy).

${ }^{66}$ Insofar as Granfinanciera's definition of public rights is inconsistent with the sovereign immunity rationale, see infra notes doctrine must rest on the executive power rationale.

${ }^{67}$ See, e.g., Freytag v. C.I.R., 501 U.S. 868, 910-11 (1991); Granfinanciera, 492 U.S. at 65-66; Crowell v. Benson 285 U.S. at 50-51. 
compensation claim in Crowell - into public ones. The Court has offered little guidance concerning how to determine whether a congressionally created right between private parties is a public right.

Moreover, it is by no means clear that the Court has definitively adopted this expanded concept of public rights. Insofar as Granfinanciera ultimately held that the action in question was a private right $^{68}$ and Thomas, in which this expanded concept originated, was ambiguous, ${ }^{69}$ the Court has never clearly held that a right arising between private parties was a public right. In addition, Granfinanciera is a Seventh Amendment case and might not be wholly applicable in the Article III context.

Another uncertainty surrounding the public rights doctrine is the doctrinal significance of characterizing the right at issue as a public right. Starting with the broad language in Murray's and reinforced by the sovereign immunity rationale, the traditional statement of the doctrine long assumed that public rights adjudications could be vested exclusively in administrative agencies with no judicial involvement. This complete exclusion approach is reflected in Crowell, Marathon, and Granfinanciera. Thomas and Schor, on the other hand, treat the type of right involved as merely a factor in a larger analysis. As noted previously, the application of this approach might require some judicial review of public right determinations, but would apparently permit that review to be very sharply limited.

Although the public rights doctrine is rife with doctrinal confusion, our more fundamental objection to the doctrine, as currently understood, is that it is inconsistent with the rule of law. Moreover, as we will develop in the following section, the current doctrine rests on a fundamental misunderstanding of Murray's Lessee. Once this misunderstanding is corrected, a coherent and more constrained public rights doctrine comes into view. This new understanding explains why first instance administrative adjudication of public rights is constitutionally permissible and it clarifies that the public rights doctrine, properly understood, has no bearing on the question of judicial review.

${ }^{68}$ See supra notes ___ and accompanying text.

69 The Court actually stated that although the right arose between private parties, it bore many of the characteristics of a public right because it was a congressionally created right integral to a comprehensive regulatory regime. See supra notes __ and accompanying text. This language actually implies that the right was a private right, and Granfinanciera's misrepresent Thomas insofar as the Court suggested that the language in Thomas defined public rights. 


\section{STANDARDS-BASED JUDICIAL REVIEW}

19

\section{Rethinking Public Rights}

This section will offer an alternative interpretation of the public rights doctrine of Murray's Lessee based on the recognition that the "public right" in that case was not a right asserted against the government, but rather a right asserted by the government on behalf of the public. This interpretation leads to two critical conclusions. First, the sovereign immunity rationale for the public rights doctrine simply makes no sense as a justification for the result in the case. Second, the government's role is relevant not because it could invoke sovereign immunity, but rather because the assertion of public rights by government actors is an executive act even when it resembles adjudication. Because it is an executive act, administrative adjudication is consistent with Article III. This rationale, however, says nothing about whether judicial review of such action may be foreclosed.

\section{The REAL MURRaY'S LESSEE}

Murray's Lessee is a difficult case with complex facts, convoluted arguments and arcane language. The Court, moreover, failed to explain what it meant by the term, "public rights," leaving readers to infer the meaning from its reasoning. This may explain why courts and commentators tend to repeat its broad language regarding public rights without a careful examination of what the Court was really talking about or the significance of this discussion in context. Unpacking the real Murray's Lessee ${ }^{70}$ however, is essential to a true understanding of the public rights doctrine.

The case arose as an "action of ejectment" involving a dispute between private parties over title to land originally owned by a man named Samuel Swartwout. ${ }^{71}$ Swartwout was a customs collector for the United States who had failed to remit to the federal government over \$1 million in customs payments that he collected. ${ }^{72}$ Congress had

70 Justice Scalia's concurrence in Granfinanciera is a notable judicial exception, but as we shall develop, Justice Scalia got Murray's Lessee only half right. For other academic treatments of Murray's Lessee, see James E. Pfander, Article I Tribunals, Article III Courts, and the Judicial Power of the United States, 118 HARV. L. REV. 643, 731-40 (2004); Gordon G. Young, Public Rights and the Federal Judicial Power: From Murray's Lessee Through Crowell to Schor, 35 BUFF. L. REV. 765 (1986).

7159 U.S. (18 How.) at 274.

${ }^{72}$ See id. 
authorized the Treasury Department to audit the accounts of tax collectors, subject to judicial review, and to recover any deficiencies by issuing a distress warrant against their property. Pursuant to this authority, the government determined a deficiency, seized land owned by Swartwout, and sold it in a distress sale to the persons who became the defendants in Murray's Lessee. ${ }^{73}$ Swartwout, who had disappeared, did not seek judicial review of the audit or contest the seizure and sale of his property.

Swartwout had also defaulted on debts to private creditors, and one of them was the plaintiff in the case. Swartwout's creditor sought to attach the land purchased by the defendants at the distress sale to satisfy the debt. He made two arguments against the validity of the government's seizure and sale of the Swartwout's land. First, he argued that distress warrant procedure violated due process, but the Court rejected this argument in light of a history of summary execution against the property of defaulting tax collectors. ${ }^{74}$ Second, he argued that the distress warrant procedure violated separation of powers. The origin of the public rights doctrine is found in the Court's resolution of the plaintiff's second argument.

The Court's analysis of the separation of powers issues began with the recognition that there was an inevitable overlap between executive and judicial actions, insofar as many executive actions involve the determination of facts and the application to them of legal rules. ${ }^{75}$ The Court expressed "little doubt" that the type of audit that the Treasury Department undertook could be the subject of judicial power ${ }^{76}$ but concluded that it could also be resolved by the executive branch. ${ }^{77}$ The Court justified this conclusion on the basis of historical understandings, referencing the practices of both federal and state governments in the United States as well as those of the British government. ${ }^{78}$

The plaintiff did not dispute these premises, but rather argued that,

${ }^{73}$ See id. at $274-75$

${ }^{74}$ See id. at 275-80. In light of longstanding British, state, and federal practices, the Court concluded, while “'due process of law' generally implies and includes actor, reus, judex, regular allegations, opportunity to answer, and a trial according to some settled course of judicial proceedings," there are exceptions to this rule under which "process, in its nature final, issues against the body, lands, and goods of certain public debtors without any such trial." Id. at 280.

${ }^{75}$ See id. at $280-81$.

${ }^{76} \mathrm{Id}$. at 281.

${ }^{77}$ See id. at 281-82.

${ }^{78}$ See id. at 281-82. 


\section{STANDARDS-BASED JUDICIAL REVIEW}

21

having made the matter subject to judicial review, Congress could not authorize the Executive branch to make the initial audit and determination of default. In other words, the plaintiff's argument was that Congress could not divide responsibility for the matter between the executive and judicial branches, but rather was required to vest the determination either entirely in the courts or entirely in the executive branch. $^{79}$ The Court introduced the "public rights" concept in response to this argument to explain why the matter could be resolved by a procedure that employed both the executive and judicial branches.

The Court disputed the premises of the plaintiff's argument, which wrongly assumed "that the entire subject matter is or is not, in every mode of presentation, a judicial controversy essentially and in its own nature, aside from the will of congress to permit it to be so; and it leaves out of view the fact that the United States is a party." point in the analysis that the Court made its oft-repeated pronouncement that "there are matters, involving public rights, which may be presented in such form that the judicial power is capable of acting on them, and which are susceptible to judicial determination, but which Congress may or may not bring within the cognizance of the courts of the United States, as it may deem proper." $" 81$

Thus, the function of the public rights doctrine in Murray's Lessee was to explain why the application of law to fact in the first instance could be assigned to an executive agency in the first instance and yet be subject to judicial review. It is based on the recognition that executive and judicial functions often overlap because both may involve the determination of facts and the application to them of the law. In light of this overlap, Congress has broad discretion concerning the allocation of authority between the two branches. As we shall see, however, this discretion does not include the foreclosure of judicial review.

\section{MURRAY'S LESSEE AND SOVEREIGN IMMUNITY}

The assumption that Congress may foreclose review derives from the conventional, sovereign immunity-based understanding of the public rights doctrine. This conventional understanding emerges naturally from some of the Court's language in Murray's Lessee, but it is wrong. There is language in the opinion emphasizing that the government is a party to the dispute. It is also true that the Court assumed that sovereign

\footnotetext{
${ }^{79}$ Id. at 282.

${ }^{80} \mathrm{Id}$. at 283.

${ }^{81}$ Id. at 284.
} 
immunity would preclude a remedy against the government in the absence of congressional consent. Nonetheless, even in Murray; Lessee itself, the sovereign immunity rationale for the public rights doctrine makes no sense.

To begin with, sovereign immunity simply was not implicated on the facts in Murray's Lessee. The case involved an action between two private parties. The defendant's claim derived from the government, but resolving the dispute would not require any remedy against the government. ${ }^{82}$ Moreover, Congress did create a judicial remedy for a wrongful accounting by the Treasury, although Swartwout had failed to pursue it. ${ }^{83}$ Maybe Congress did not have to create the remedy, but that issue was simply not before the Court and any pronouncements about it are clearly dicta.

On the facts of Murray's Lessee, moreover, the argument that sovereign immunity would have given Congress the power to preclude judicial review of the accounting, seizure, and sale proves either too much or too little. The property seized by the government pursuant to the warrant - land owned by Swartwout - was traditional private property. ${ }^{84}$ Thus, if sovereign immunity converts the administrative attachment and sale of private property into a public right as to which no judicial remedy is required, the government can use summary procedures to take whatever private property it might choose and leave the owner without recourse. This would surely convert the Takings Clause into a hollow shell. ${ }^{85}$ By similar logic the government could violate any

${ }^{82}$ If the seizure and sale had been undertaken by a foreign government in its own territory, the act of state doctrine would apply to protect the sovereign power of the foreign government from review by United States courts. cite But that doctrine does not apply to judicial review of actions by the federal government.

${ }^{83}$ See supra note ___ and accompanying text.

84 A different situation would be presented if the government had only attached the actual tax monies Swartwout failed to remit or property that was directly traceable to it, but the statute in question permitted the warrant to attach to all of a tax collector's land, see id. at 274, and there was no suggestion in the case that Swartwout had purchased the land with tax monies.

${ }^{85}$ In First English Evangelical Lutheran Church v. County of Los Angeles, 482 U.S. 304, 315-316 \& n. 9 (1987), the Court indicated that the Fifth Amendment provided a self-executing constitutional remedy for takings violations, and rejected the argument that the principle of sovereign immunity altered that conclusion. Nonetheless, Justice Scalia took the opposite view in his dissent in Webster v. Doe, 486 U.S. 592, 613 (1988): "No one would suggest that, if Congress had not passed the Tucker Act, 28 U.S.C. $\$ 1491(a)(1)$, the courts would be able to order disbursements from the Treasury to pay for 
constitutional right with impunity simply by acting first and declining to waive sovereign immunity. Of course, we doubt that the Court would accept this logic, but if Murray's Lessee is based on sovereign immunity, there would not appear to be any basis for drawing a distinction between government benefits and private property. ${ }^{86}$

One might confine the implications of the sovereign immunity rationale in Murray's Lessee by limiting it to the context of a defaulting tax collector or similar claims, which present special circumstances that might justify the use of summary administrative procedures. The temptations of collecting large sums of money and the potential consequences to the public fisc arguably create a special need for speedy and effective remedies in the case of a default. Thus, a tax collector's particular responsibilities arguably justify imposing the acceptance of summary procedures as a condition of employment. These features of the case were emphasized in the earlier portions of the Court's opinion in Murray's Lessee addressing the due process issue. ${ }^{87}$ Confined in this manner, however, the public rights doctrine is quite narrow, and certainly would not support its extended application in the modern administrative state.

The assumption that because of sovereign immunity Congress can preclude judicial review of government benefit claims was also contrary to Supreme Court precedent as it stood at the time of Murray's Lessee. ${ }^{88}$ In an often unnoticed passage in Marbury, Chief Justice Marshall distinguished between sovereign immunity in personal injury actions, as to which the common law presumed that the king could do no wrong, and injury to property, for which the law " furnishes various methods of detecting the errors and misconduct of those agents by whom the king has been deceived and induced to do a temporary injustice." ${ }^{, 89}$ Thus, Marbury assumes that sovereign immunity does not preclude remedies

property taken under lawful authority (and subsequently destroyed) without just compensation." See Robert Brauneis, The First Constitutional Tort: The Remedial Revolution in Nineteenth-Century State Just Compensation Law, 52 Vand. L. Rev. 57, 137-39 (1999) (discussing sovereign immunity constraints on recovery for government takings). A detailed exposition of this fascinating issue is beyond the scope of this Article. It should be evident, however, where we would come out.

${ }^{86}$ See supra notes _ \& accompanying text.

${ }^{87}$ See supra notes _ \& accompanying text.

${ }^{88}$ It is also contrary to more recent understandings of sovereign immunity. See supra notes __ and accompanying text.

${ }^{89} 5$ U.S. (1 Cranch) at 166 (citing Blackstone, Vol. III. p. 255). 
against government officials who violate the law..$^{90}$

Even more directly relevant is United States v. Nourse, ${ }^{91}$ an 1835 decision involving the very statute at issue in Murray's Lessee, in which Chief Justice Marshall was emphatic that sovereign immunity did not bar suits against government officials:

It would excite some surprise if, in a government of laws and principle, furnished with a department whose appropriate duty it is to decide questions of right, not only between individuals, but between the government and individuals; a ministerial officer might, at his discretion, issue this powerful process, and levy on the person, lands, and chattels of the debtor, any sum he might believe to be due, leaving to that debtor no remedy, no appeal to the laws of his country, if he should believe the claim to be unjust. But this anomaly does not exist; this imputation cannot be cast upon the legislature of the United States. ${ }^{92}$

In short, whether sovereign immunity would have precluded review of the audit of Swartwout's accounts and subsequent sale of his property was by no means clear at the time of Murray's Lessee.

\section{EXECUTIVE POWER IN MURRAY's LESSEE}

Ultimately, sovereign immunity does not work as an explanation for the public rights doctrine in Murray's Lessee because that reasoning is based on a misreading of what the court meant by public rights. Public rights are not public because they are asserted against the government. Public rights are public because they belong to the public. Because the enforcement of rights belonging to the public is an executive function, public rights determinations that resemble adjudications can be assigned

${ }^{90}$ Similarly, in his later discussion of the propriety of a writ of mandamus, Marshall indicated that the same remedies were available against government officials as against private parties. See 5 U.S. (1 Cranch) at 170:

If one of the heads of departments commits any illegal act, under colour of his office, by which an individual sustains an injury, it cannot be pretended that his office alone exempts him from being sued in the ordinary mode of proceeding, and being compelled to obey the judgment of the law. How then can his office exempt him from this particular mode of deciding on the legality of his conduct, if the case be such a case as would, were any other individual the party complained of, authorize the process?

${ }^{91} 34$ U.S. (9 Pet.) 8 (1935).

${ }^{92} I d$. at 28-29. 


\section{STANDARDS-BASED JUDICIAL REVIEW}

25

to administrative agencies. ${ }^{93}$ This perspective thus provides a foundation for the executive power rationale for public rights. It also means, however, that the doctrine is relevant only to first instance adjudication and has no bearing on the question of judicial review. ${ }^{94}$

The Court in Murray's Lessee suggested the executive power rationale for administrative adjudication at the outset of its separation of powers analysis. The Court noted that while "the auditing of the accounts of a receiver of public moneys may be, in an enlarged sense, a judicial act, . . . [s]o are all of those administrative duties the performance of which involves inquiry into the existence of facts and the application to them of rules of law." $" 95$ The Court then gave examples of other executive actions which are judicial in this sense, including calling forth the militia pursuant to statute and seeking extradition of prisoners pursuant to treaty. ${ }^{96}$ This surprisingly modern explanation of the overlap between executive and judicial power makes clear that the Court's focus is on the characterization of the actions in question, not sovereign immunity.

Even more significant is a passage that comes immediately before the Court's famous pronouncement on public rights. In this passage the Court elaborated on how a matter could be subject to both executive and judicial cognizance by reviewing "some settled rules":

Though, generally, both public and private wrongs are redressed through judicial action, there are more summary extrajudicial remedies for both. An instance of extra-judicial redress of a

${ }^{93}$ See Craig A. Stern, What's A Constitution Among Friends - Unbalancing Article III, 146 U. Pa. L. Rev. 1043, 1062 (1998) ("What makes a matter one of public rights is ... whether the right is one that falls to the executive to determine as a matter of public administration, at least for the time being.").

${ }^{94}$ In Marbury, for example, the delivery (or nondelivery) of the commission in question was an executive act, but it also involved the application of law to fact in the sense that Madison made an initial determination of whether Marbury was entitled to the commission. The propriety of allocating this initial decision to the executive branch was not in doubt, but it did not follow that judicial review was foreclosed. To the contrary, it was implicitly required by the rule of law. In the same sense, a determination that a claimant is or is not entitled to a particular government benefit may be one that may be assigned initially either to the executive branch or the judiciary, but that does not answer the question whether, if it assigned to the executive, judicial review may be foreclosed.

${ }^{95}$ Id. at 280. This functional analysis of the overlap between executive and judicial action has a surprisingly current ring to it.

${ }^{96} I d$. 
private wrong is, the recapture of goods by their lawful owner; of a public wrong, by a private person, is the abatement of a public nuisance; and the recovery of public dues by a summary process of distress, issued by some public officer authorized by law, is an instance of redress of a particular kind of public wrong, by the act of the public through its authorized agents. ${ }^{97}$

We believe that the Court's reference to "public wrongs" is an oftenoverlooked antecedent referent for the concept of "public rights." After all, a "public wrong" is simply the violation of a "public right" or a right belonging to the public. ${ }^{98}$

Consider, for example, the Court's use of a public nuisance to illustrate a public wrong that may be redressed by the actions of a private party. According to well-established law, a "public nuisance is based on an infringement of the rights of the community, must affect an interest in common to the general public, and unlike a private nuisance, does not necessarily involve ownership or use of land by either party." 99 In other words, a public nuisance violates rights that belong to the public. Governmental enforcement of such rights is properly assigned to the executive branch.

Once it is recognized that the concept of public rights in Murray's Lessee referred to the government's pursuit of extrajudicial remedies to protect the public interest, the Court's discussion of the overlap between executive and judicial power comes into sharper focus. When Congress enacts a statute, the public interest served by that statute may be enforced by means of the Article III adjudication if Congress provides for a private right of action (private enforcement) or for a government enforcement action. Alternatively, Congress can authorize extrajudicial remedies that may be privately or publicly enforced. The enforcement by government officials of both judicial and extrajudicial remedies is a traditional executive function. Both kinds of executive action, moreover, require that officials make judgments about the facts and the application of the law to those facts.

${ }^{97} I d$. at 283.

${ }^{98}$ This is also Justice Scalia's understanding of a public right, which he nonetheless links with the sovereign immunity rationale for the doctrine. See supra notes __ and accompanying text. As we discuss more fully below, if our understanding of the meaning of a "public right" is correct, however, it has nothing to do with sovereign immunity, as suggested by Justice Scalia. See infra notes __ and accompanying text.

${ }^{99}$ Robert L. Glicksman, A Guide to Kansas Common Law Actions Against Industrial Pollution Sources, 33 KAN. L. REV. 62, 643 (1985) 


\section{STANDARDS-BASED JUDICIAL REVIEW}

27

This view of the public rights doctrine may provide an explanation for the Court's current view that rights arising between private parties may be regarded as "public" rights if they are an integral part of the enforcement of a comprehensive regulatory regime. ${ }^{100}$ The Court has never fully explained this expanded concept of public rights, but once it is understood that "public rights" refer to rights belonging to the public, a coherent rationale emerges. The key point is that because the initial determination of the dispute between private parties is incidental to the enforcement of the regulatory regime (i.e., the vindication of public rights), it can be described as executive in character even though it involves the application of law to fact. ${ }^{101}$

Critically, the executive power explanation of the public rights doctrine explains why first instance administrative decisions resembling adjudication are constitutionally permissible, but does not justify the foreclosure of judicial review. The Court in Murray's Lessee may have assumed that sovereign immunity would have barred judicial relief absent congressional consent, but as we have seen that assumption was unnecessary to the decision and incorrect as a matter of law. Under Marbury, executive action subject to legal standards is subject to judicial review for compliance with those standards. Congressional authority to permit the first instance administrative adjudication of rights between private parties may well be constrained by other separation of powers concerns, ${ }^{102}$ but it does not threaten the rule of law if administrative procedures comply with due process and judicial review is available.

A proper understanding of the public rights doctrine makes clear that the constitutionality of precluding or limiting judicial review of administrative decisions should be resolved without regard to whether a public right is involved. With this jurisprudential underbrush cleared away, it is possible to consider the foreclosure of judicial review from a fresh perspective, unclouded by assumptions engendered by the public rights doctrine. We turn to this task in the following section.

${ }^{100}$ See note __ \& accompanying text.

101 This was arguably the case in Thomas, for example, where the rights arising between private parties were incident to the enforcement of a pesticide registration scheme. See supra notes and accompanying text.

${ }^{102}$ Likewise, the Seventh Amendment may apply to such determinations. Our view of the public rights doctrine would permit first instance administrative adjudication, but the Seventh Amendment might require that a jury trial be available at some point. We will not delve into the question whether such trials could be held by administrative adjudicators (or legislative courts). 


\section{ForECLOSURE OF JUDiCIAL REVIEW}

The rule of law suggests two possible constraints on the foreclosure of judicial review: due process and Article III. Ironically, while the due process and Article III preclusion cases do not reference each other and there has been no authoritative resolution of either issue, the Court has ended up in roughly the same place in both areas. Under current doctrine it appears that Congress probably cannot preclude judicial review of colorable constitutional claims, but it can preclude judicial review of ordinary decisions determining facts and applying statutory standards.

\section{A. Due Process}

Beginning with American School of Magnetic Healing $v$. McAnnulty, ${ }^{103}$ through the leading case of Johnson v. Robison, ${ }^{104}$ and culminating with a number of more recent decisions, the Supreme Court has relied on due process to require review of administrative decisions notwithstanding statutory provisions that apparently foreclosed it. Some of these cases employ broad rule of law reasoning that is reminiscent of Marbury, but more recent cases focus narrowly on the foreclosure of particular constitutional claims. This has led many commentators to assume that due process requires a judicial forum for constitutional claims (and the Supreme Court has suggested as much), but that due process does not apply to foreclosure of review for ordinary administrative decisions.

The McAnnulty case is an early example of broad rule of law reasoning. The case arose when the Postmaster General determined that claims by the School of Magnetic Healing that it could teach its customers how to use the power of the mind to cure sickness were fraudulent, and stopped delivery of the company's mail. ${ }^{105}$ When the company challenged this action in court, the Postmaster General argued that judicial review of the decision was foreclosed because the statute in question authorized such action upon evidence "satisfactory to him.,"106

The Supreme Court disagreed, reasoning that because the Postmaster General's action "was a clear mistake of law as applied to admitted facts

\footnotetext{
103187 U.S. 94 (1902).

104415 U.S. 361 (1974).

${ }^{105}$ See 187 U.S. at 95-102 (recounting the facts and proceedings in detail).

${ }^{106}$ See Rev. Stat. § 3929 (quoted 187 U.S. at 100 n.1).
} 


\section{9}

\section{STANDARDS-BASED JUDICIAL REVIEW}

. . the courts must have power in a proper proceeding to grant relief."107 "Otherwise," the Court continued, "the individual is left to the absolutely uncontrolled and arbitrary action of a public and administrative officer, whose action is unauthorized by any law, and is in violation of the rights of the individual. Where the action of such an officer is thus unauthorized, he thereby violates the property rights of the person whose letters are withheld."108 Notwithstanding this broad language, the Court expressly declined to reach Magnetic Healing's constitutional claim, but rather "construed" the statute to permit review. ${ }^{109}$

McAnnulty takes a broad rule of law-based approach to due process and arguably implies that judicial review of the legality of administrative action is constitutionally required. Some subsequent cases, such as Leedom v. Kyne, ${ }^{110}$ seem to endorse a similar approach, at least to the extent of requiring review when administrative decisions violate a clear statutory provision creating a right. ${ }^{111}$ These cases are limited, however, in important respects. First, while they require review for obvious statutory violations, they seem to assume that review may be foreclosed for more run of the mill cases involving the application of law to the facts. McAnnulty, for example, assumed that "the determination by the Postmaster General of any material and relevant questions of fact arising in the administration of the statutes of Congress relating to his department" was conclusive."112 Second, because they rely on statutory

${ }^{107} 187$ U.S. at 110.

${ }^{108}$ Id. See also id. at 108 (asking rhetorically "Has Congress intrusted the administration of these statutes wholly to the discretion of the Postmaster General, and to such an extent that his determination is conclusive upon all questions arising under those statutes, even though the evidence which is adduced before him is wholly uncontradicted, and shows, beyond any room for dispute or doubt, that the case, in any view, is beyond the statutes, and not covered or provided for by them?").

${ }^{109} \mathrm{Id}$. at 101-02.

110358 U.S. 185 (1958).

${ }^{111}$ See also Bowen v. Michigan Academy of Family Physicians, 476 U.S. 667, 680 (characterizing the contention that Congress "intended no review at all of substantial constitutional and statutory challenges to the Secretary's administration of Part B of the Medicare program" as "an extreme position") (emphasis added); Oestereich v. Selective Serv. Sys. Local Bd. No. 11, 393 U.S. 233 (1968) (construing statute precluding review of selective service classification except as a defense to a criminal prosecution so as to permit an injunction against a violation of the plain and unequivocal language of other provisions of the statute).

${ }_{112} 187$ U.S. at 107; see also Leedom v. Kyne, 358 U.S. at 188-91 
interpretation to avoid constitutional problems, the cases leave the existence of an underlying constitutional right of review unresolved.

Most of the cases refusing to permit the foreclosure of review focus on review of particular constitutional claims. The leading example of this sort of decision is Johnson v. Robison, ${ }^{113}$ which involved equal protection and free exercise challenges to the denial of veteran's benefits to individuals who had been classified as conscientious objectors and performed alternative civilian service. The Court considered (and rejected) these claims notwithstanding a statute providing that there was to be no judicial review of "any question of law or fact" arising under any law administered by the Veteran's Administration. ${ }^{114}$ The Court reasoned that this provision did not foreclose review of constitutional challenges to the statute denying benefits because such challenges arise under the Constitution, not under any veterans benefit law. ${ }^{115}$

Although the Court in Robinson did not discuss the constitutional difficulties that might arise from a construction that precluded judicial review of constitutional claims, this problem was clearly lurking in the background. In the aftermath of Robison, the Court has frequently construed broad statutory language precluding review to permit adjudication of constitutional claims. ${ }^{116}$ In these cases, the Court often

(distinguishing prior cases recognizing foreclosure of review on the ground that in this case the NLRB violated a clear statutory provision granting a right); Oesterreich, 393 U.S. at 238-399 (employing similar reasoning).

113415 U.S. 361 (1974).

114 Former 38 U.S.C. $\$ 211$ (a) (quoted id. at 365 n.5) provided that "the decisions of the Administrator on any question of law or fact under any law administered by the Veteran's Administration providing benefits for veterans and their dependents or survivors shall be final and conclusive and no other official or any court of the United States shall have power or jurisdiction to review any such decision by an action in the nature of mandamus or otherwise."

115 This distinction was articulated expressly by Justice Brandeis in his concurring opinion in St. Joseph Stock Yards Co. v. United States, 298 U.S. 38, 77 (1936), which stated that "[w]hen dealing with constitutional rights (as distinguished from privileges offered by the government) there must be the opportunity of presenting in an appropriate proceeding at some time, to some court, every question of law raised." More recently, in Dalton v. Specter, 511 U.S. 462, 471-76 (1994), the Court sharply distinguished between constitutional and statutory claims, holding that statutory challenges to military base closure decisions were foreclosed under the applicable statute

116 See, e.g., I.N.S. v. St. Cyr., 533 U.S. 289 (2001) (construing baring review of deportation of aliens to permit review of pure questions of law because foreclosure of such review would raised serious constitutional questions as to whether the writ of habeas corpus had been unconstitutionally suspended); 


\section{1}

\section{STANDARDS-BASED JUDICIAL REVIEW}

accepted, at least implicitly, the constitutionality of the statute as applied in nonconstitutional cases. ${ }^{117}$

In light of these decisions, most commentators assume that it would violate due process to deny a judicial forum for the resolution of constitutional claims, and the Court has often suggested the same in dicta. ${ }^{18}$ By comparison, the Court in recent years has seemed increasingly willing to read ambiguous statutes as foreclosing review when constitutional claims are not involved, and nothing in the reasoning of these cases suggests that there are any constitutional problems with reading the statutes in question to foreclose review. ${ }^{119}$ The Court, for example, articulated a reverse presumption against review when prosecutorial inaction is at issue in Heckler $v$. Chaney. ${ }^{120}$ Subsequently, in Lincoln v. Vigil, ${ }^{121}$ the court held that allocation of lump-sum appropriations is "committed to agency discretion" and thus foreclosed from review under the Administrative Procedure Act. ${ }^{122}$

\section{B. Article III And The Exceptions Clause}

McNary v. Haitian Refugee Center, 498 U.S. 479 (1991) (construing statute precluding review of decisions on applications for immigration amnesty to permit a due process challenge to procedures followed); Webster v. Doe, 486 U.S. 592 (1988) (construing statute barring review of decisions by the Director of the CIA to dismiss employees so as to permit review of constitutional claims); see also Bowen v. Michigan Academy of Physicians, 476 U.S. 667 (1986) (construing statute vesting review of Medicare reimbursement claims involving small amounts to private fiscal intermediaries without judicial review so as to permit constitutional and statutory challenges to agency regulations).

${ }^{117}$ In Webster v. Doe, for example, the Court upheld portions of a lower court's decision holding that review of a former CIA's procedural and statutory challenges to his termination was foreclosed. 486 U.S. 592, 600 (1988).

118 See, e.g., Thomas, 473 U.S. at 592-93; Martin H. Redish \& Curtis E. Woods, Congressional Power to Control the Jurisdiction of Lower Federal Courts: A Critical Review and Synthesis, 124 U. Pa. L. Rev. 45, 93 (1975) ("There exists a due process right to an independent judicial determination of constitutional rights ....").

${ }^{119}$ Likewise, one leading administrative law textbook observes that in the lower courts "[t]here seems to be a modest trend in favor of finding agency decisions committed to agency discretion." STEPHEN G. BREYER, RICHARD B. Stewart, Cass R. Sunstein \& Matthew L. Spitzer, Administrative LaW AND Regulatory POLICY 1014 ( $5^{\text {th }}$ ed. 2002) (citing cases). The authors continue, however, that "the trend remains modest and cautious, and judicial review is the general rule." Id. (citing cases).

${ }^{120} 470$ U.S. 821 (1985).

121508 U.S. 182 (1993).

${ }^{122} I d$. at $192(1993)$. 
In addition to the due process issues discussed above, the preclusion of judicial review also has Article III implications because when Congress precludes review, it removes a category of cases "arising under" federal law from the cognizance of the federal courts. ${ }^{123}$ The constitutionality of such "jurisdiction stripping" statutes requires an interpretation Article III with special reference to Exceptions Clause. In this section, we review the debate over Congress's power to strip the federal courts of jurisdiction over certain cases or controversies, and offer an alternative interpretation of the Exceptions Clause.

\section{THE JURISDICTION STRIPPING DEBATE}

Taken on its face, the language of the Exceptions Clause might appear to grant Congress broad discretion to remove cases and controversies from the jurisdiction of the federal courts:

In all Cases affecting Ambassadors, other public Ministers and Consuls, and those in which a State shall be Party, the supreme Court shall have original Jurisdiction. In all the other Cases before mentioned, the supreme Court shall have appellate Jurisdiction, both as to Law and Fact, with such Exceptions, and under such Regulations as the Congress shall make. ${ }^{124}$

This reading, however, cannot be reconciled with the constitutional role that Marbury assigns to the courts. As a result, the authority of Congress to remove cases from the jurisdiction has confounded the Court, producing no clear answer, and has given rise to one of the oldest and most extensive debates concerning the federal courts. This debate, which includes a famous dispute between Professors Henry Hart and Hebert Weschler, ${ }^{125}$ and which is the subject of substantial attention in

123 Congressional restrictions on judicial review can take four different forms. First, Congress might withdraw Supreme Court jurisdiction but retain federal district court jurisdiction. Second, it might withdraw federal district court jurisdiction, but permits suits in state court that are subject to Supreme Court review.. Third, Congress could withdraw all federal jurisdiction but allow suits in state courts. Finally, Congress could bar review in any court. See HART \& WECHSLER, supra note __, at 358-380 (distinguishing and discussing these situations). Our focus is on the fourth possibility. It is an interesting question of federalism whether state court review of federal administrative action would satisfy the rule of law, but we find it unnecessary to address this hypothetical possibility.

${ }^{124}$ U.S. Const. Art. III, § 2, cl. 2 (emphasis added).

125 Compare Henry M. Hart, Jr., The Power of Congress to Limit the 


\section{3}

\section{STANDARDS-BASED JUDICIAL REVIEW}

each of the major federal courts casebooks, ${ }^{126}$ has produced no less than four different proposed resolutions. ${ }^{127}$ The standards-based approach offers an attractive alternative to these resolutions.

No less a figure than Justice Story took the position that, under Article III, the entire judicial power must vest somewhere in the federal courts, a proposition that formed the premise of his argument for appellate jurisdiction over state court decisions in Martin v. Hunter's Lessee. ${ }^{128}$ This view draws strength from general separation of powers doctrine and the rule of law, insofar as removal of cases from the jurisdiction of the courts deprives them of the ability to "say what the law is." While this position has some supporters, ${ }^{129}$ it is difficult to reconcile with the Exceptions Clause and has never commanded a clear majority of the Court. Currently, a variety of statutory provisions exclude at least some categories of Article III cases and controversies decisions from the jurisdiction of the federal courts. ${ }^{130}$

Jurisdiction of Federal Courts: An Exercise in Dialectic, 66 HARV. L. REV. 1362 (1953) (arguing that Congress may not limit jurisdiction so as to destroy the essential function of the courts) with Herbert Wechsler, The Courts and the Constitution, 65 ColuM. L. REV. 1001 (1965) (arguing that Congress has the authority to decide the extent to which federal courts would be used).

126 See Michael G. Collins, Robert N. Clinton \& Richard A. Matasar, Federal Courts, Theory AND PraCtice 33-73 (1996); DAVID P. CURRIE \& HARry N. WyATt, FEDERAL COURTS: CASES AND MATERIALS 98-113 ( $4^{\text {th }}$ Ed. 1990); Richard H. FAllon, DANIEl J. MElTZER \& DAVID ShapIRO, HART \& WeChSLER'S THE FEDERAL COURTS AND THE FEDERAL SySTEM 348-87 ( $4^{\text {th }}$ ed 1996); HowARD P. FinK, LindA S. MulleniX, THOMAS D. ROWE, JR. \& Mark V. Tushnet, Federal CoURTS In THE $21^{\text {ST }}$ CENTURY 163-91 (1995).

127 See ERWIN ChEMERINSKY, CONSTITUTIONAL LAW: PRINCIPLES AND POLICIES 165-77 (2d ed. 2002) (describing four different approaches taken on the issue of jurisdictional stripping).

12814 U.S. (1 Wheat.) 304, 330 (1816) (If, then, it is a duty of congress to vest the judicial power of the United States, it is a duty to vest the whole judicial power) (emphasis in original).

129 See, e.g., Akhil Amar, The Two Tiered-Structure of the Judiciary Act of 1789, 138 U. PA. L. REV. 1499; Robert N. Clinton, A Mandatory View of Federal Court Jurisdiction: A Guided Quest for the Original Understanding of Article III, 138 U. PA. L. REV. 1596; Theodore Eisenberg, Congressional Authority to restrict Lower Federal Court Jurisdiction, 83 YALE L.J. 498 (1974); Leonard Ratner, Congressional Power over the Appellate Jurisdiction of the Supreme Court, 109 U. PA. L. REV. 157 (1960); see also Lawrence Sager, Foreward: Constitutional Limitations on Congress' Authority to Regulate the Jurisdiction of the Federal Courts, 95 HARV. L. REV. 17, 55 (1981) (opposing selective withdrawal of jurisdiction).

${ }^{130}$ See generally NOWAK \& ROTUNDA, supra note at 36-47. 
At the other extreme is the view that Congress has plenary authority to create exceptions to the jurisdiction of federal courts whenever it chooses. ${ }^{131}$ The Court appeared to endorse this view in Ex parte McCardle, ${ }^{132}$ which dismissed a constitutional challenge to incarceration by Reconstruction era military governments on the ground that Congress had repealed the Supreme Court's jurisdiction to consider appeals of habeas corpus petitions. The opinion contains broad language suggesting that Congress has unlimited power to strip the federal courts of jurisdiction pursuant to the Exceptions Clause. ${ }^{133}$ Nevertheless, the Court was also careful to note that the repeal of the statute did not completely prevent the consideration of the matter by the Court because an alternative basis for jurisdiction - a petition for writ of certiorari remained available. ${ }^{134}$ The Court has subsequently backed away from the broad language of McCardle, most notably in United States $v$. Klein, ${ }^{135}$ which rejected a congressional effort to strip the courts of jurisdiction to decide the effect of a presidential pardon.

Since the broad language of McCardle is inconsistent with Marbury's conception of the judicial function, the Court and most commentators have moved to something of an uneasy middle ground. Among the intermediate positions are the view that the "essential functions" of the judiciary must be preserved $^{136}$ and the view that congressional authority to divest the courts of jurisdiction must be exercised in conformity with other constitutional provisions. ${ }^{137}$ These interpretations accept the initial proposition that the Exceptions Clause authorizes Congress to remove cases entirely from the jurisdiction of the

${ }^{131}$ See Gerald Gunther, Congressional Power to Curtail Federal Court Jurisdiction: An Opinionated Guide to the Ongoing Debate, 36 STAN. L. REV. 895 (1984).

${ }^{132} 74$ U.S. (7 Wall.) 506 (1869).

${ }^{133}$ See id. at 514 ("We are not at liberty to inquire into the motives of the legislature. We can only examine into its power under the Constitution; and the power to make exceptions to the appellate jurisdiction of this court is given by express words.").

${ }^{134}$ See id. at 515 ("Counsel seem to have supposed, if effect be given to the repealing act in question, that the whole appellate power of the court, in cases of habeas corpus, is denied. But this is an error. The act of 1868 does not except from that jurisdiction any cases but appeals from Circuit Courts under the act of 1867. It does not affect the jurisdiction which was previously exercised."). Later that same year the Court exercised that jurisdiction in Ex parte Yerger, 75 U.S. 8 (Wall.) 85 (1869).

13580 U.S. (13 Wall.) 128 (1871).

${ }^{136}$ This was Hart's view. See supra note

${ }^{137}$ See NOWAK \& ROTUNDA, supra note at $39-40$. 
federal courts, but attempt to identify some external constitutional limits on that power.

\section{An ALTERNATIVE INTERPRETATION OF THE EXCEPTIONS Clause}

We believe, however, that there is an alternative interpretation of the Exceptions Clause that is more consistent with the text of Article III as a whole and more consistent with the rule of law. ${ }^{138}$ In our view, the best reading of the Exceptions Clause is that it concerns the allocation of cases between the Supreme Court's original and appellate jurisdiction, and does not authorize Congress to remove cases and controversies within the scope of federal jurisdiction from the Article III courts. ${ }^{139}$ Thus, it provides no authority for the preclusion of review.

Article III vests and defines the judicial power of the United States in mandatory terms. Section 1 provides that the "judicial Power of the United States, shall be vested" in the Supreme Court and lower courts. ${ }^{140}$ Likewise, Section 2 provides that the "judicial Power shall extend" to certain categories of cases and controversies. ${ }^{141}$ The natural reading of this language is that the full extent of the judicial power must be vested in the federal courts. This construction would parallel the provisions of Articles I and II, both of contain vesting clauses that are generally understood to be mandatory. Thus, reading the vesting clause of Article III as anything other than mandatory would thus be anomalous and an understanding of the Exceptions Clause that permits Congress to preclude appellate review of administrative action is at odds with the other provisions of Article III.

$138 \mathrm{We}$ focus on these considerations because the historical material concerning the Exceptions Clause is "at best, incomplete." Michael L. Wells \& Edward J. Larson, Original Intent and Article III, 70 TULANE L. REV. 75 (1995).

$139 \mathrm{We}$ are not the first to contend the Exceptions Clause addresses the allocation of cases between the Supreme Court's original and appellate jurisdictions. See Dean Alfange, Jr, Marbury v. Madison and Original Understandings of Judicial Review: in Defense of Traditional Wisdom, 1993 SuP. CT. REV. 329, 397 \& n.313 (collecting authorities); see also Mark Strasser, Taking Exception to Traditional Exceptions Clause Jurisprudence: On Congress's Power to Limit the Court's Jurisdiction, 2001 UTAH L. REV. 125. Contra Akhil R. Amar, Marbury, Section 13, and the Original Jurisdiction of the Supreme Court, 56 U. CHI. L. REV. 443, 447 (1989); James E. Pfander, Marbury, Original Jurisdiction, and the Supreme Court's Supervisory Powers, 101 Colum. L. REV. 1515 (2001).

${ }^{140}$ U.S. Const. Art III, $\$ 1$ (emphasis added).

${ }^{141}$ U.S. Const. Art III, $\S 2$, cl. 1 (emphasis added). 
The Exceptions Clause is likewise poorly drafted if its purpose was to permit Congress to remove cases entirely from the Article III judiciary. The Clause provides: "In all the other Cases before mentioned, the supreme Court shall have appellate Jurisdiction, both as to Law and Fact, with such Exceptions, and under such Regulations as the Congress shall make."142 Critically, the Clause is not a qualification of the language in Section 1 that vests of the judicial power in the federal courts or of the language in section 2 listing the cases and controversies within the jurisdiction of the federal courts, which would be the logical phrasing if its purpose was to permit removal of cases from the courts' authority and jurisdiction.

Instead, the exceptions language is in a clause allocating the original and appellate jurisdiction of the Supreme Court. Moreover, since the Clause specifies that the original jurisdiction of the Surpeme Court "shall" include certain classes of cases and that in all other cases its jurisdiction "shall" be appellate, the language carries forward the implication that the vesting of jurisdiction is mandatory. Finally, and most fundamentally, the power to make exceptions is phrased not in reference to the jurisdiction of federal courts generally, but in reference to the appellate jurisdiction of the Supreme Court. ${ }^{143}$

Both the context of the Clause and its language make it sensible to read the Exceptions Clause as addressing the allocation of cases between the Supreme Court's original and appellate jurisdiction. The first sentence of the Clause sets forth the classes of cases that, at a minimum, must be within the Court's original jurisdiction and the Exceptions Clause permits Congress to add to that jurisdiction by moving cases from the Court's appellate to its original jurisdiction. ${ }^{144}$

\footnotetext{
${ }^{142}$ U.S. Const. Art III, § 2, cl. 2.

${ }^{143}$ For this reason, Ron Levin has suggested that the historical purpose of the Exceptions Clause was to permit Congress to exempt jury verdicts from de novo appellate review. See Ronald M. Levin, Identifying Questions of Law in Administrative Law, 74 GEO. L.J. 1, 20 n.118 (1985) (citing The Federalist No. 81 (Hamilton) and Henry J. Merry, Scope of the Supreme Court's Appellate Jurisdiction: Historical Basis, 47 MINN. L. REV. 53 (1962).

${ }^{144}$ Chief Justice Marshall's reasoning in Marbury justified the inference of exclusivity on the basis that this was the only reading that gave any effect to the language in question. 5 U.S. (1 Cranch) at 174-75. But this assumption is simply not true. The Clause makes perfect sense as a minimum requirement of original jurisdiction cases that can be enlarged, but not diminished. We recognize the irony of relying heavily on Marbury's rule of law analysis but ultimately rejecting the reading of Article III that provided the basis for the assertion of
} 
In contrast to the conventional reading of the Exceptions Clause, the allocational interpretation provides a logically coherent account of the Clause and its role in Article III as a whole. The classes of cases listed in the first sentence of the Clause are especially important to the federal system, and it makes sense to specify that they fall within the Supreme Court's original jurisdiction. ${ }^{145}$ Likewise, it is reasonable to provide for the enlargement of the Court's original jurisdiction to include other cases that Congress considers sufficiently important to warrant the exercise of that jurisdiction. At the same time, this reading of the Exceptions Clause does not permit Congress to encroach upon the essential functions of the judiciary by excluding cases from the jurisdiction of the federal courts, and thus avoids any contradiction with the mandatory language of the Vesting Clause and Article III's definition of the judicial power.

\section{STANDARDS-BASED JUDICIAL REVIEW}

In this section of the Article we explain our standards-based approach to the rule of law and how it applies to judicial review of government benefit decisions. We also explain why we think it is superior to both the current doctrine and alternative approaches that have been suggested in the judicial review literature. Finally, we evaluate the practical significance of a constitutional mandate that requires Article III review of administrative adjudication.

\section{A. STANDARdS-BASEd Rule of LAW}

Our argument for standards-based judicial review is easily summarized. Like Chief Justice Marshall, ${ }^{146}$ we believe the Constitution establishes a rule of law state. Under the rule of law, government officials derive their authority to act from the law and they are bound by the law in exercising that authority. The lynchpin of this rule of law framework is the presence of legal standards that guide and constrain governmental authority. Thus, the rule of law ordinarily requires the legislature to incorporate standards into statutory delegations of

power to invalidate legislation as unconstitutional. Nonetheless, this disagreement with Marbury is unrelated to its rule of law reasoning.

145 Indeed, this would seem consistent with the Court's recent emphasis on the "dignity" of states. See Federal Maritime Com'n v. South Carolina State Ports Authority, 122 S.Ct. 1864, 1874 (2002) ("The preeminent purpose of state sovereign immunity is to accord States the dignity that is consistent with their status as sovereign entities.”). 
authority. When legal standards apply to official action and the rule of law applies, essential rule of law safeguards should apply, including judicial review. Thus, under the standards-based approach, Congress generally cannot preclude judicial review of factual and legal decisions concerning government benefits.

As we understand the Constitution, it promotes the rule of law in three interrelated ways. First, Congress must establish statutory standards to guide and limit Executive Branch lawmaking. This requirement, which is related to both due process and separation of powers, is enforced by the Supreme Court primarily by means of the non-delegation doctrine. Second, when government decisions are subject to statutory standards, the Due Process Clause obligates the government to give adversely affected persons some type of hearing in which they can present factual and legal arguments. Finally, adversely affected persons are entitled to judicial review of the government's decision, both as a matter of due process and separation of powers.

\section{THE REQUIREMENT OF STANDARDS}

The model of governmental regularity embodied by the rule of law implies a general principle of nonarbitrariness in governmental action. ${ }^{147}$ This principle in turn implies that governmental action must be constrained by standards. Thus, the rule of law generally requires the legislature to incorporate statutory standards to guide and control the administration of government benefits. A standardless statute violates the rule of law because it "lays down no rules by which its impartial execution can be secured, or partiality and oppression prevented.",148

A requirement of statutory standards is most closely associated with separation of powers and the nondelegation doctrine. The nondelegation is normally thought of as policing the boundary between legislative and executive action for purposes of the Vesting Clause of the Constitution, ${ }^{149}$ but it also serves a crucial rule of law function.

\footnotetext{
${ }^{146}$ See supra notes _ \& accompanying text.

${ }^{147}$ Shapiro \& Levy, supra note , at _.

148 Yick Wo v. Hopkins, 118 U.S. 356, $372-73$ (1886) (quoting City of Baltimore v. Radecke, 49 Md. 217 (1878)).

${ }^{149}$ U.S. Const. Art. I, § 1; see Whitman v. American Trucking Associations, 531 U.S. 457, 472 (2001) ("In a delegation challenge, the constitutional question is whether the statute has delegated legislative power to the agency. Article I, § 1 , of the Constitution vests '[a]ll legislative Powers herein granted ... in a Congress of the United States.' This text permits no delegation of those powers . ...”. In other words, the formulation of an initial policy decision (i.e., setting
} 
Enforcement of the doctrine separates the creation of law from its implementation and thereby constrains the action of government officials by requiring that those officials act under legally binding standards. In this sense, the requirement of standards under the nondelegation doctrine is closely akin to a line of Supreme Court cases, such as Yick Wo v. Hopkins, ${ }^{150}$ that suggest standardless administrative discretion violates due process. ${ }^{151}$

We recognize that Congress often establishes vague and ambiguous statutory standards to guide and limit Executive Action. Obviously, it may be easier for administrators to comply with broad ambiguous standards than with specific ones. Nonetheless, the presence even of general standards whose application is subject to judicial review preserves the rule of law. As explained by the Court:

Necessity therefore fixes a point beyond which it is unreasonable and impracticable to compel Congress to prescribe detailed rules; it then becomes constitutionally sufficient if Congress clearly delineates the general policy, the public agency which is to apply it, and the boundaries of this delegated authority. Private rights are protected by access to the courts to test the application of the policy in the light of these legislative declarations. ${ }^{152}$

The requirement of standards, however, is not absolute because the Constitution itself contemplates that some decisions are vested in the political discretion of the other branches. For example, the political question doctrine demarcates a class of decisions that are not subject to legal standards and therefore operate outside of the rule of law constraints that generally apply to government action. ${ }^{153}$

standards) is a legislative act, while the exercise of discretion pursuant to statutory standards is an executive act. See INS v. Chadha, 462 U.S. 919, 953 n. 16 (1983) (distinguishing between the legislative character of the legislative veto and the executive character Attorney General's decision which was vetoed because "that kind of Executive action is always subject to check by the terms of the legislation that authorized it; and if that authority is exceeded it is open to judicial review as well as the power of Congress to modify or revoke the authority entirely," while the legislative veto "is not so checked").

150118 U.S. 356, 372-73 (1886).

151 See Shapiro \& Levy, supra note , at __ (describing and discussing the cases).

${ }^{152}$ American Power \& Light Co. v. SEC, 329 U.S. 90, 105 (1946).

${ }^{153}$ See Shapiro \& Levy, supra note , at _ (describing and discussing the standardless discretion and due process). 


\section{RULE OF LAW SAFEgUARDS}

The nondelegation doctrine provides the foundation for a rule of law state by requiring that legislation must generally contain statutory standards. The Constitution creates then two essential safeguards to insure Executive Branch compliance with such standards: due process and judicial review. In our view, when the legislature delegates authority pursuant to standards, the rule of law attaches. And when the rule of law attaches so do the essential safeguards of due process and judicial review. We dealt with the due process component of this equation in our earlier article, ${ }^{154}$ the discussion here focuses on judicial review.

We believe that the preclusion of judicial review is best understood from a separation of powers perspective. Separation of powers is best known for its political function of diffusing governmental authority, ${ }^{155}$ it is also has an important rule of law purpose. ${ }^{156}$ As discussed previously, the separation of the legislative and executive functions makes it possible to ascertain and enforce legal constraints on government action. ${ }^{157}$ Like due process, separation of powers incorporates a specific mechanism for enforcing the rule of law: judicial review.

Article III provides for the establishment of a judiciary with

154 Shapiro \& Levy, supra note

155 See Federalist No. 47 (Hamilton) ("The accumulation of all powers, legislative, executive and judiciary, in the same hands, whether of one, a few, or many, and whether hereditary, self-appointed, or elective, many justly be pronounced the very definition of tyranny."); Massachusetts Constitution, Pt. 1, Art. XXX ("In the government of this commonwealth, the legislative department shall never exercise the executive and judicial powers, or either of them: the executive shall never exercise the legislative and judicial powers, or either of them: the judicial shall never exercise the legislative and executive powers, or either of them: to the end it may be a government of laws and not of men.”).

156 See AMAN \& MAYTON, supra note _, at 67 ("[A] combination of powers is bad because it admits ad hoc law making, not permanent and general laws but orders cut for the occasion--all according to the will of whomever holds combined powers. Separated powers, on the other hand work to induce government within the rule of law."); Thomas O. Sargentich, The Contemporary Debate About Legislative-Executive Separation of Powers, 72 CORN. L. REV. 430, 450 (1987) ("A close relation between the rule of law and separation of powers is evident in both the liberal and democratic elements of liberal democratic theory.").

${ }^{157}$ See supra notes __ and accompanying text (discussing the this aspect of the nondelegation doctrine. 


\section{STANDARDS-BASED JUDICIAL REVIEW}

41

jurisdiction to resolve cases and controversies, vesting the courts with authority to oversee legislative and executive compliance with legal standards. ${ }^{158}$ The framers not only established the judiciary as the guardians of rule of law, they were careful to protect the independence of the judicial branch from the other two branches, mandating that Article III judges have life-time tenure and that Congress and the President could not reduce the compensation of judges once they had been appointed. ${ }^{159}$

To the extent that current doctrine permits the foreclosure of judicial review, the application of this essential rule of law safeguard is dependent upon legislative discretion. ${ }^{160}$ Interpreting Article III to permit foreclosure of review puts Congress in the position of determining if and when a litigant is entitled to the Article III protections of an independent judiciary, which is inconsistent with a constitutional structure that mandates separation of powers. Congress violates the separation of powers when it precludes Article III review because this choice makes Executive Branch the ultimate authority of determining its own compliance with statutory standards. ${ }^{161}$

Nor can the preclusion of judicial review be justified on the ground that Congress is dealing with government benefits as opposed to traditional "private property." 162 A government action that violates statutory standards is every bit as much a violation of the rule of law when it concerns the allocation of government benefits as when it concerns private property rights. In both cases, government agents have failed to obey the legal standards that control their actions. We therefore see no distinction between government benefits and private property in respect to the application of the rule of law.

Finally, from a separation of powers perspective, judicial review by Article III courts cannot be replaced by internal administrative appeals or appeals to so-called Article I courts. Appellate judges in the Executive Branch do not have the constitutionally mandated independence needed to hold the Executive Branch in check. We are not

${ }^{158}$ U.S. Const. Art. III, §2.

${ }^{159} I d$. at $\S 1$.

${ }^{160}$ See supra notes _ \& accompanying text.

${ }^{161}$ In effect, the executive becomes judge in its own cause. See supra notes _ \& accompanying text.

${ }^{162}$ As we develop in considerable detail in our due process article, the historical significance of this distinction is vastly overstated. See Shapiro \& Levy, supra note at 119-26. 
entirely sure what the difference is between an administrative agency that adjudicates cases and an Article I court, except the court's location outside of the agency whose adjudications it reviews. Even if this arrangement promotes the independence of Article I courts, they are still inconsistent with the constitutional plan for separation of powers. ${ }^{163}$

Moreover, if something less than article III status were sufficient to meet the requirements of the rule of law, it would be necessary to determine how much independence is enough. If life tenure is not required, what term of years is sufficient to guarantee independence? What bases for removal "for cause" are permissible without compromising independence? Can these judges be independent if their salaries are not protected? These questions are not entirely academic. As discussed below, there is evidence that some Article I courts in fact lack the necessary separation and independence to supply critical scrutiny of agency adjudications. ${ }^{164}$

\section{SCOPE OF REVIEW}

The standards-based approach to the rule of law thus suggests that administrative determinations involving application of law to facts must be subject to judicial review ${ }^{165}$ and that total preclusion of judicial

${ }^{163}$ We would note that no commentator that we can find argues that Article I review is an adequate constitutional substitute for Article III review, although there is a difference of opinion concerning the minimum scope of Article III review. See infra notes __ and accompanying text. Unlike most other commentators, we would require judicial review of both legal and factual decision s made in government benefit decisions.

${ }^{164}$ See infra notes __ and accompanying text (discussing Article I review of disability determinations of the Veterans Administration).

165 This conclusion can be accommodated with sovereign immunity. Marbury certainly implied that sovereign immunity is not a bar to review, and as demonstrated in part II, sovereign immunity is not relevant to a proper understanding of the public rights doctrine. Although sovereign immunity is clearly in considerable tension with the rule of law, the doctrine has received new life in the Supreme Court's recent federalism decisions, see, e.g., Seminole Tribe v. Florida, 517 U.S. 44 (1996) (holding that Congress may not abrogate $11^{\text {th }}$ Amendment immunity pursuant to the commerce power and overruling Pennsylvania v. Union Gas Co., 491 U.S. 1 (1989)); Alden v. Maine, 527 U.S. 706 (1999) (extending sovereign immunity to action against states in state courts); Florida Prepaid Postsecondary Education Expense Bd. v. College Savings Bank, 527 U.S. 627 (1999) (same); College Savings Bank v. Florida Prepaid Postsecondary Education Expense Bd., 527 U.S. 666 (1999) (same); see also Kimel v. Florida Board of Regents, 528 U.S. 62 (2000) (applying Alden). Moreover, it seems unlikely that the Supreme Court would repudiate sovereign 


\section{STANDARDS-BASED JUDICIAL REVIEW}

43

review in such cases would be a violation of the rule of law. On the other hand, the rule of law would not ordinarily require a trial de novo by Article III courts. Deferential review would be permissible provided sufficient scope of review is retained to permit reviewing courts to fulfill their rule of law function. First, courts must retain the power to "say what the law is," at least to the point of correcting violations of the clear statutory text or failure to apply correctly statutory standards or factors. Second, courts must have the authority to ensure that there is a valid factual basis for executive action. Third, courts must be able to review the rationality of the connection between the facts found and the statutory basis for action. ${ }^{166}$

The federal courts must retain jurisdiction to review the factual determinations made by executive branch adjudicators, because without such authority, the courts are not in a position to ensure compliance with the law. Factual findings can be manipulated to evade legal constraints and judicial review could easily be evaded if it did not include review of factual determinations as well as legal conclusions. ${ }^{167}$ This recognition is reflected in the text of Article III itself, which provides that the Supreme Court's appellate jurisdiction extends to both "Law and

immunity as to federal government. Nonetheless, sovereign immunity should not stand as a complete bar to judicial review, because suits against government officials for declaratory and injunctive relief are available under the doctrine of Ex Parte Young, 209 U.S. 123 (1908). The Court's federalism cases emphasize that this avenue for the vindication of federal statutory and constitutional rights remains available. See, e.g., Alden, 527 U.S. at 756-57.

While this form of review may not make damages available, if government benefits are wrongly withheld courts would presumably be able to require administrative officials to comply with the law. A critical issue might be whether a reviewing court must be able to order the disbursement of monetary benefits, insofar as the Court has held that federal courts may not order retroactive payment of benefits unlawfully withheld by state officials under the Eleventh Amendment. See Edelman v. Jordan, 415 U.S. 651 (1974). There is, however, a critical difference between ordering a state (or the federal government) to pay damages for a tortious act and requiring state or federal officials to award someone a government benefit for which the person is legally entitled and for which a state or Congress has appropriated a money to pay such benefits.

${ }^{166}$ See Sidney A. Shapiro and Richard E. Levy, Heightened Scrutiny of the Fourth Branch: Separation of Powers and the Requirement of Adequate Reasons for Agency Decisions, 1987 DUKE L. J. 387 (1987) (contending that judicial review of an agency's reasons is constitutionally required).

${ }^{167}$ See Allentown Mack Sales and Service v. NLRB, 522 U.S. 359, 376 ("An agency should not be able to impede judicial review, and indeed even political oversight, by disguising its policymaking as factfinding.") 
Fact." ${ }^{168}$ For this reason, the Supreme Court has at times engaged in de novo review of "constitutional facts" that determine the outcome of individual rights claims. ${ }^{169} \mathrm{We}$ do not suggest that judicial review of agency findings in ordinary cases must be de novo, but the courts must retain sufficient review of facts and the application of law to facts to preserve the rule of law.

In general terms, current scope of review doctrine under the Administrative Procedure Act satisfies these requirements, ${ }^{170}$ but more limited review may violate the rule of law. In particular, we have doubts about the current veteran's benefit regime, which precludes Article III review of factual determinations except as to constitutional facts, ${ }^{171}$ and the limitation of review in Thomas v. Union Carbide to issues of fraud, misconduct, or misrepresentation or constitutional error. ${ }^{172}$

${ }^{168}$ U.S. Const. Art. III, § 2.

${ }^{169}$ In Crowell v. Benson, for example, the Court suggested that there must be de novo review of administration decisions respecting both constitutional and "jurisdictional" facts, construing the statute in question to permit it. See supra note __ and accompanying text. Although the jurisdictional fact doctrine has fallen into disuse and de novo review of constitutional facts is not consistently applied, these doctrines underscore the need for some factual review to prevent abuse. See, e.g., Bose Corp. v. Consumer's Union, 466 U.S. 485 (1984) (engaging in independent review of trial court's finding of actual malice to support First Amendment defense to product disparagement claim); Norris v. Alabama, 294 U.S. 587 (1935) (rejecting state court factual determination that African-Americans were not excluded from the jury pool); see generally Henry P. Monaghan, Constitutional Fact Review, 85 Colum. L. Rev. 229 (1985).

1705 U.S.C. $\$ 706$ permits reviewing courts to set aside agency decisions, inter alia, if they are contrary to law, arbitrary and capricious, or not supported by substantial evidence (in formal adjudications). Under Chevron U.S.A., Inc., 467 U.S. 837 (1984), courts may reverse an administrative construction of a statute if the construction violates the clear statutory text or is otherwise based on an impermissible or unreasonable construction of a statute. Under either the substantial evidence or arbitrary and capricious standard of review courts may reverse agency decisions that are not supported by an adequate factual basis in the record. The arbitrary and capricious standard of review also requires that the agency articulate the connection between the facts found and the choice made, and this form of review focuses on the adequacy of the agency's explanation. See Motor Vehicle Mfrs. Ass'n v. State Farm Mut. Auto Ins. Co., 463 U.S. 29 (1983).

${ }^{171}$ In particular, under 38 U.S.C. $§ 7292(d)(2)\left(200 \_\right)$, the United States Court of Appeals for the Federal Circuit, which has exclusive jurisdiction over veterans benefit appeals, "may not review (A) a challenge to a factual determination, or (B) a challenge to a law or regulation as applied to the facts of a particular case," except for constitutional claims.

${ }^{172}$ See supra notes ___ (discussing limitation of review of arbitral awards 


\section{STANDARDS-BASED JUDICIAL REVIEW}

45

Whether statutes limiting review by restricting the timing of review or limiting the parties who may seek review present a problem would depend on the circumstances. Except perhaps where delay would lead to the permanent loss of an irreplaceable interest, the preclusion statutes that affect only the timing of judicial review would not present a serious problem. On the other hand, partial preclusion statutes that prevent particular parties from seeking review, ${ }^{173}$ are problematic if they leave those injured by the improper application of legal standards without a remedy.

\section{Foreclosure of ReVIEW AND POLITICAL DisCretion}

Judicial review would be required for most government benefit decisions under the foregoing analysis. The only exception would be when the Constitution itself contemplates standardless political discretion. In such cases, the rule of law does not attach and neither does the requirement of judicial review. Indeed, this aspect of the standardfs-based approach helps to make sense of prominent cases in which the Court has upheld foreclosure of review.

In Heckler v. Chaney, ${ }^{174}$ for example, the Court held that prosecutorial decisions by administrative officials are presumptively nonreviewable. The Court's analysis of this issue focused on separation of powers concerns and emphasized that like prosecutorial discretion in criminal matters, administrative prosecution is a function that "has long been regarded as the special province of the Executive Branch ...."175 Indeed, while prosecutorial discretion cannot be exercised in violation of constitutional rights (e.g., in a racially discriminatory manner), it is generally subject to standardless discretion.

Other preclusion decisions can be explained in similar terms. National security considerations within the President's foreign relations powers were implicated in Webster $v$. Doe ${ }^{176}$ which held that decisions of the Directer of the CIA to terminate an employer were not reviewable (except for constitutional claims). ${ }^{177}$ Likewise, Lincoln v. Vigil, which

\footnotetext{
under FIFRA to claims of fraud, misconduct, or misrepresentation, or constitutional error).

${ }^{173}$ See, e.g., Block v. Community Nutrition Institute, 467 U.S. 340 (1984),

${ }^{174} 470$ U.S. 821 (1985).

${ }^{175} \mathrm{Id}$. at 832 .

176486 U.S. 592 (1988).

${ }^{177}$ Id. at 600-05.
} 
refused to review a decision by the Indian Health Service not to fund a medical facility, can be explained in terms of traditional executive prerogatives relating to the allocation of discretionary budget items. ${ }^{178}$

We do not anticipate that this exception would justify Congress in giving the Executive Branch standardless discretion over most government benefits. ${ }^{179}$ Decisions about welfare benefits, licenses, and most government jobs do not require that government officials have unfettered discretion in order to make the government run more effectively. The exception would come into play, however, concerning some forms of government employment, because of the President's unique role for the oversight of executive officials, including the appointment and removal of those officials. ${ }^{180}$ For similar reasons, it might also apply to some government contracts and grants.

\section{B. OTHER VieWS}

As noted earlier, although there is an extensive literature on the extent to which Congress can foreclose judicial review, we are the first to offer a standards-based theory that requires Article III review of the initial administrative adjudication of facts and law in government benefit claims. While some other commentators argue that at least some form of judicial review is constitutionally compelled, we argue in this part that our standards-based approach is preferable to approach taken by these other commentators.

\section{Public Rights}

The administrative adjudication literature is for the most part highly critical of the public rights doctrine, challenging its historical foundations, its conceptual incoherence, and its fundamental inconsistency with the rule of law. ${ }^{181}$ Nevertheless, most of the

178508 U.S. 182, 192 (1993) ("The allocation of funds from a lump-sum appropriation is another administrative decision traditionally regarded as committed to agency discretion.").

${ }^{179}$ See Shapiro \& Levy, supra note , at 138-39 (discussing this exception to standards requirement).

${ }^{180}$ See $i d$. at $140-41$ (discussing the political discretion exception as applied to public employment).

${ }^{181}$ See, e.g., AMAN \& MAYTON, supra note _, at 126 ("Because the public and private rights distinction ... allows the courts' important federal question jurisdiction to be allocated to agencies without reference to Article III or its purposes, the distinction is surely deficient."); Fallon, supra note __, at 953 ("to the extent that [the public rights doctrine] displaces checks against arbitrary 


\section{STANDARDS-BASED JUDICIAL REVIEW}

47

commentary assumes that the doctrine exempts administrative adjudication of public rights entirely from Article III, ${ }^{182}$ and that the doctrine would have to be abolished in order to ensure some form of judicial review. ${ }^{183}$ Commentators who favor abolishing the public rights doctrine would replace it with the balancing test announced by the Court in Schor or some variation of it. Professor Richard Fallon is the leading proponent of this approach. His "appellate review theory" of judicial review posits that "when Congress chooses to employ a non-article III federal adjudicator, it must provide for judicial review of at least some issues in a constitutional court." 184

and self-interested government action, the doctrine threatens the rule of law"). For additional commentary critical of the public rights doctrine, see Paul M. Bator, The Constitution as Architecture: Legislative and Administrative Courts under Article III, 65 IND. L.J. 233, 250 (1990) ("For even if the 'public rights' category were an intelligible and manageable category (which it is plainly not), we still have not been told why the category is congruent with cases where the use of an article I court or administrative agency is valid."); Martin H. Redish, Legislative Courts, Administrative Agencies, and the Northern Pipeline Decision, 1983 DUKE L.J. 197, at 210 (discussing the constitutional flaws in the public-rights doctrine) Judith Resnik, The Mythic Meaning of Article III Courts, 56 U. CoLO.L.REv. 581, 592-602 (1985) (arguing that the Article III safeguards are especially necessary in public rights cases); Gordon G. Young, Public Rights and the Federal Judicial Power: From Murray's Lessee Through Crowell to Schor, 35 BUFF. L. REV. 765, 837 (1986) (criticizing the public-rights doctrine from a separation-of-powers perspective); see also Kenneth S. Klein, The Validity of the Public Rights Doctrine in Light of the Historical Rationale of the Seventh Amendment, 21 HASTINGS CONST. L.Q. 1013 (1994) (arguing against the constitutional validity of the public-rights doctrine with respect to the Seventh Amendment); Kenneth S. Klein, The Validity of the Public Rights Doctrine in Light of the Historical Rationale of the Seventh Amendment 21 HASTINGS CONST. L.Q. 1013 (1994) (arguing that the history of the Seventh Amendment does not support the application of the public rights doctrine).

${ }^{182}$ See, e.g. Glen O. Robinson, ERNEST GELLHORN \& HAROLD H. BRUFF, The AdMinistrative Process 163 ( $4^{\text {th }}$ ed. 1993) (The Supreme Court has "approved foreclosure of review of nonconstitutional claims, and the prevailing assumption since Crowell has been that judicial review of public right claims is not required.) (citation omitted).

${ }^{183}$ Professor Stern is a notable exception. He reviews Murray's Lessee and notes, as we do, that the facts and reasoning of the case do not address the foreclosure of review, but he does not fully explain the public rights doctrine. See Craig A. Stern What's a Constitution among Friends?-Unbalancing Article III, 146 U. PA. L. REV. 1043, 1062-63 (1998); see also Joshua I. Schwartz Nonacquiescence, Crowell v. Benson, and Administrative Adjudication, 77 GEO. L.J. 1815, 1883-85 (1989) (arguing that Murray's Lessee and Crowell do not support foreclosure of judicial review of public rights cases).

${ }^{184}$ Fallon, supra note __, at 949 . See also Richard B. Saphire \& Michael 
Our understanding of the public rights doctrine causes us to take a different route. As we discussed previously, ${ }^{185}$ the public rights doctrine is best understood as standing for the proposition that extrajudicial action to enforce rights belonging to the public is executive action. From this perspective, the doctrine permits executive action resembling adjudication in the first instance, but says nothing about the foreclosure of judicial review. Thus, we do not see the public rights doctrine as incompatible with a general constitutional requirement of judicial review of executive action. The doctrine may therefore continue to play an important role in assessing the constitutionality of first instance adjudication by agencies (or legislative courts). ${ }^{186}$

We also reject use of a balancing test to determine when Article III review must be employed. Whether the foreclosure of review is consistent with the rule of law, under either a due process or Article III approach, can and should be resolved by reference to Marbury's understanding of the judicial role in enforcing the rule of law. Under this approach, Article III review is required for all agency adjudications in order to preserve the rule of law except where the Constitution contemplates that Congress can authorize Executive Action without establishing standards for such action.

\section{Due Process}

E. Solimine Shoring up Article III: Legislative Court Doctrine in the Post CFTC v. Schor Era, 68 B.U. L. REv. 85 (1988) (arguing that judicial review should be required under the $S c h o r$ test).

${ }^{185}$ See supra notes _ \& accompanying text.

${ }^{186}$ In light of the Court's longstanding recognition of the doctrine and its role in preserving the constitutionality of first instance administrative adjudication (without juries), we doubt that the Court is prepared to directly repudiate it. In a similar vein, Professor Fallon concludes that the doctrine is too well-ensconced to be rejected, but seeks to narrow its scope to render it consistent with his appellate review theory of Article III. See Fallon, supra note _ administrative adjudication, provided that sufficient judicial review is retained, other Article III considerations, such as preserving the structural balance of the three branches, as well as the Seventh Amendment, are implicated by administrative adjudication in the first instance. Whether the public rights doctrine is an appropriate component of the analysis of these issues is beyond the scope of this article. For analysis of the Seventh Amendment issues, see Kenneth S. Klein, The Validity of the Public Rights Doctrine in Light of the Historical Rationale of the Seventh Amendment 21 HASTINGS CONST. L.Q. 1013 (1994); Ellen Sward, Legislative Courts, Article III, and the Seventh Amendment, 77 N.C.L. REV. 1037 (1999). 


\section{STANDARDS-BASED JUDICIAL REVIEW}

Many scholars approach foreclosure of judicial review from a due process perspective, ${ }^{187}$ drawing on the Supreme Court's cases suggesting that preclusion of review may violate due process. ${ }^{188}$ While preclusion of review may violate due process, the due process approach is ill suited to provide a coherent account of judicial review, which is primarily a separation of powers safeguard and is best understood from that perspective. ${ }^{189}$

Under current doctrine, due process only attaches to government decisions that deprive a person of a protected liberty or property interest. When government benefit decisions are involved, this doctrine permits Congress to evade due process safeguards by declining to create an entitlement. Thus, linking judicial review to due process would not, under current doctrine, prevent Congress from foreclosing review (by declining to create an entitlement). ${ }^{190}$

Even when there is a protected interest, the availability of judicial review under current doctrine would appear to be a question of what process is due and therefore subject to Matthews $v$. Eldridge's instrumental calculus. ${ }^{191}$ Thus, judicial review would be available only if it could be shown that the benefits of judicial review in terms of increased accuracy exceed its costs. This approach accords no value to the systemic interest in preserving the rule of law.

187 See Weinberg, supra note ___ (arguing that due process, not Article III, should be the primary referent for considering congressional authority to limit the jurisdiction of federal courts); see also Richard Fallon, Some Confusions About Due Process, Judicial Review, and Constitutional Remedies, 93 CoLuM. L. REV. 309, 332-35 (1993) (analyzing due process right of review).

${ }^{188}$ See supra notes _ \& accompanying text.

${ }^{189}$ To the extent that due process reflects the rule of law generally, judicial review and due process are linked. But we think the constitutional safeguards for the rule of law are best understood within the context of the particular provisions from which they derive. Thus, procedural safeguards are best analyzed from a due process perspective and judicial review is best analyzed in terms of Article III and the separation of powers.

${ }^{190}$ This and other problems with the current approach to due process were the focus of our earlier article, which advances the standards-based approach to the rule of law as a solution. See Shapiro \& Levy, supra note

${ }^{191}$ For an application of Matthews to the question of judicial review, see Note, Congressional Preclusion of Judicial Review of Federal Benefit Disbursement: Reasserting Separation of Powers, 97 HARV. L. REV. 778 (1984) (arguing that Matthews prevents complete preclusion of review). 
In the final analysis, absent a comprehensive reformulation of due process doctrine, the Due Process Clause does not provide a secure foundation for judicial review. ${ }^{192}$ None of the commentators supporting the due process approach to judicial review have offered such a reformulation of the doctrine. More fundamentally, treating judicial review as a component of due process diminishes its constitutional role. Judicial review is more than a particular procedural safeguard; it is a core rule of law requirement.

\section{ARTICLE III}

In the "huge" body of scholarly comment on the power of Congress to restrict federal jurisdiction in light of Article III, ${ }^{193}$ the only consensus is that the issues are unlikely to be resolved definitively in the foreseeable future. Much of the traditional debate has focused on the meaning of Article III's jurisdictional provisions. While some scholars join us in reading the mandatory language of these provisions as requiring that the entire judicial power must vest in Article III courts, ${ }^{194}$ the majority of commentators reject this view. Nevertheless, most of majority recognizes some constraints on congressional authority to limit the jurisdiction of federal courts. ${ }^{195}$

One influential view posits that Congress may not use its jurisdictional authority to interfere with the "essential functions" of the judiciary. This approach "essential" asks whether a particular preclusion of review "will destroy the essential role of the Supreme Court in the constitutional plan"196 or undermine the distribution of authority

192 Of course, our standards-based approach to due process might be one such comprehensive reformulation and it would eliminate the problem of whether due process attaches. See Shapiro \& Levy, supra note __. But our approach does not challenge the Mathews $v$. Eldridge, which - with some tweaking - we consider to be an acceptable mode of inquiry for determining whether particular procedural safeguards are required. Id. at 141-42.

${ }^{193}$ See Howard P. Fink, Linda S. Mullenix, Thomas D. Rowe, Jr. \& Mark V. Tushnet, Federal CourTs IN THE $21^{\text {ST }}$ CENTURY 181 (1996) (referring to the "huge" literature and describing it). As noted earlier, this is one of the oldest and most famous debates regarding the federal courts. See supra notes and accompanying text

${ }^{194}$ See supra notes __ \& accompanying text.

195 Some commentators, however, do argue that Congress has plenary authority to restrict federal jurisdiction. See Gerald Gunther, Congressional Power to Curtail Federal Court Jurisdiction: An Opinionated Guide to the Ongoing Debate, 36 STAN. L. REV. 895 (1984).

196 Henry Hart, The Power of Congress to Limit the Jurisdiction of the Federal Courts: An Exercise in Dialectic, 66 HARV. L. REV. 1362, 1365 (1953); 


\section{STANDARDS-BASED JUDICIAL REVIEW}

51

between the judiciary and the other branches of government. ${ }^{197}$ Because this approach focuses on broader structural issues, it tends to submerge rule of law concerns and does not fully account for the individual interest in governmental regularity.

Many scholars, for example, assume that the essential functions approach does not require judicial review of statutory, as opposed to constitutional, claims. It remains unclear, however, why there is any less need for judicial review when statutory rights are involved. The concerns about rule of law are the same in both cases. ${ }^{198}$ To the extent some commentators use essential functions analysis to argue for a broad requirement of judicial review in every case, ${ }^{199}$ we think the standardsbased rule of law approach provides a superior conceptual framework because it explains why judicial review is an "essential" function.

Even among scholars who would require review of statutory interpretation and other legal issues, there is a split of opinion concerning whether some judicial review of fact-finding is also necessary. ${ }^{200}$ This difference of opinion tends to derive from the structural separation of powers perspective of those who advocate mandatory review. Limiting judicial review of fact-finding in a narrow group of statutory cases would not necessarily unbalance the three branches of government by interfering with the essential functions of the

Ratner, supra note ___ (arguing that the essential functions approach precludes Congress from negating the Supreme Court's appellate jurisdiction over any given subject on the ground that it would prevent the Court from its essential function of maintaining the uniformity and supremacy of federal law).

197 Peter Strauss, The Place of Agencies in Government, Separation of Powers and the Fourth Branch, 84 COLUM. L. REV. 573, _ (1984).

198 See Louise Weinberg, The Article III Box: The Power of "Congress" to Attack the "Jurisdiction" of "Federal Courts", 78 TEX. L. REV. 1405, 1424 (2000) ("[T]here is no good reason why a claimant with a merely statutory claim against a federal official should have less access to an apolitical forum than a claimant with a constitutional claim.")

199 The leading exponent of this "appellate review theory" is Richard Fallon. See Fallon, supra note __ and accompanying text.

${ }^{200}$ Compare Saphire \& Solimine, supra note __, at 139 (requiring judicial review of both factual and legal determinations) with Fallon, supra note __, at 987 (requiring judicial review only of legal issues and establishing a presumption against judicial review of factual issues) and Paul M. Bator, The Constitution As Architecture: Legislative and Administrative Courts Under Article III, 65 IND. L. REV. 233, 267-28 (1990) (requiring judicial review of legal issues, but not of factual issues as long as agency procedures comport with due process). 
judiciary or unduly trammeling on the constitutional authority of the federal courts.

We disagree that Congress can preclude judicial review of factfinding by the Executive Branch. Our disagreement arises from two points made earlier. First, unconstrained discretion over the factual determinations that provide the predicate for lawful government action can defeat the rule of law. ${ }^{201}$ Second, appellate review in the Executive Branch is insufficient to protect the rule of law. ${ }^{202}$ We therefore conclude the rule of law requires at least some judicial review of administrative factual determinations and of the application of law to facts. This conclusion is supported by our reading of the text of Article III, which specifically refers to the Supreme Court's appellate jurisdiction as extending to "Law and Fact."203

\section{Practical Implications}

The debate about judicial preclusion is longstanding and extensive with federal courts scholars, in particular, taking a range of positions. This debate, however, has mostly ignored the rule of law considerations that we regard as of the utmost constitutional significance. We believe the rule of law is significant not only as a matter of constitutional principle, but for practical reasons as well. Along with procedural due process, judicial review is an essential safeguard against errors and abuse by government officials.

While some observers are skeptical of the value of judicial review and assume that the costs of judicial intervention in administrative decisions outweigh its benefits, ${ }^{204}$ our understanding is different. Judicial review of the Social Security Administration (SSA) in the 1980s demonstrates the important role that judicial review plays in preserving the rule of law. More recent experience with the Veterans Administration (VA) suggests the independence of Article III judges is a crucial element of that role.

After the election of President Ronald Reagan, SSA adopted a series of highly restrictive policies and practices that resulted in sharply

\footnotetext{
${ }^{201}$ See supra notes __ \& accompanying text.

${ }^{202}$ See supra notes __ \& accompanying text.

${ }^{203}$ U.S. CONST., Art. III. § 2, cl. 2.

204 See, e.g., Richard J. Pierce, The Due Process Counterrevolution of the 1990s?, 96 COLUM. L. REV. 1973 (1996).
} 


\section{STANDARDS-BASED JUDICIAL REVIEW}

53

increased rates of denial or termination of benefits. ${ }^{205}$ While some of these policies and practices and resulting denials and terminations were legitimate responses to concerns about abuse of the system, the SSA itself admitted that it wrongfully terminated benefits to hundreds of thousands claimants. ${ }^{206}$ Moreover, the courts found that many of the SSA's policies and practices were contrary to applicable statutory standards and in some instances flagrantly so. ${ }^{207}$ Although the SSA often resisted these judicial decisions through a formal policy of "nonacquiescence" 208 and used unpublished policies and bureaucratic practices to influence nominally independent administrative decisionmakers, ${ }^{209}$ it was eventually forced to abandon or modify most of its restrictive practices. ${ }^{210}$

Most observers agree that judicial review was an essential safeguard for the rule of law in the administration of Social Security benefits. ${ }^{211}$

205 See Susan Gluck Mezey, No Longer Disabled: The Federal Courts and the Politics of the Social Security Administration (1988); Debra Cofer, Judges, Bureaucrats and the Question of Independence: A Study of the Social Security Administration Hearing Process (1985); Richard E. Levy, Social Security Disability Determinations: Recommendations for Reform, 1990 B.Y.U. L. Rev. 461 (Report prepared for the Federal Courts Study Committee).

206 See Schweicker v. Chilicky 487 U.S. 412, 416 (1988).

207 See, e.g., City of New York v. Heckler, 578 F. Supp. 1109 (E.D.N.Y. 1983) (finding that SSA had employed an illegal and clandestine policy of presuming that claimants who did not meet regulations defining per se disabling ailments disabilities could perform unskilled work without regard to individual circumstances of claimants), aff'd, 742 F.2d 729 (2d Cir. 1984), aff'd sub nom. Bowen v. City of New York, 476 U.S. 467 (1986); see also Mental Health Ass'n v. Schweicker, 554 F. Supp. 157 (D.Minn. 1982) (same), aff'd sub nom. Mental Health Ass'n v. Heckler, 720 F.2d 965 ( $8^{\text {th }}$ Cir. 1983).

208 Under the nonacquiescence policy, the SSA would issue rulings specifically directing administrative decisionmakers to apply regulations or policies that had been invalidated by federal courts of appeals, even in the circuits where the decisions were rendered. See Levy, supra note __, at 503-07

209 For example, under the "Bellmon Review Program" the SSA targeted administrative law judges with high rates of allowing benefits for review on the agency's own motion. Id. at 497-99. Other practices are described at id. 484506.

${ }^{210}$ See, e.g., id. at $485 \&$ n. 126 (citing authorities)

211 Examples include the authorities cited supra note One notable exception is Professor Richard Pierce, who has argued that the judiciary overstepped its bounds in the area of Social Security. See Richard Pierce, Political Control Versus Impermissible Bias in Agency Decisionmaking: Lessons from Chevron and Mistretta, 57 U. CHI. L. REV. 481, 501-515 (1990). Professor Pierce's opposition to judicial review is longstanding and consistent, 
Certainly, administrative appeals within SSA did not provide sufficient protection and indeed were part of the problem. It is possible that an Article I court would have had greater independence and therefore provided adequate protection for beneficiaries, but experience with the VA suggests that Article I courts are not always sufficiently independent of the agencies they review.

Prior to 1989, Congress precluded any Article III review of VA disability decisions. In 1989, Congress responded to longstanding and nearly unanimous complaints by veterans associations about the lack of fair and responsive adjudication by the VA by adopting the Veterans Judicial Review Act. ${ }^{212}$ The Act established what is now known as the Court of Appeals for Veterans Claims (CAVC), an Article I court, to review the factual and legal conclusions of the VA. ${ }^{213}$ The CAVC's decisions are subject to review by the United States Court of Appeals for the Federal Circuit, which has Article III status, but this review does not include factual determinations or the application of statutes or regulations to the facts of a particular case. ${ }^{214}$

The VA disability adjudication system, however, continues to be highly dysfunctional. ${ }^{215}$ The VA has over 600,000 pending claims, ${ }^{216}$ and the agency takes an average of two and one-half to three years to

but we respectfully submit that it is also wrong.

212 See Lawernce B. Hagel \& Michael P. Horan, Five Years Under the Veterans' Judicial Review Act: The VA Is Brought Kicking and Screaming Into the World of Meaningful Due Process, 46 Me. L. Rev. 43, 44-45 (1994) (describing the events leading to the passage of the Veterans Judicial Review Act).

213 See Veterans Judicial Review Act, Pub. L. No. 100-687, 102 Stat. 4105 (1989) (defining organization, jurisdiction, procedure and other provisions of the new court). Congress also authorized the Federal Circuit to engage in limited review of CAVC decisions. See 38 U.S.C. § 7292(d)(1) (establishing jurisdiction to review CAVC decisions only on its interpretation of governing statutes).

214 See 38 U.S.C. $§ 7292$ (d)(2) (expressly precluding such issues from the scope of Federal Circuit review). This exclusion does not apply to constitutional claims, however. Id.

${ }^{215}$ For general discussion, see Richard E. Levy, Of Two Minds: Charitable and Social Insurance Models in the Veteran's Benefits System, 13 KAN. J.L. \& POL'Y 303 (2004) (arguing that retention of a charitable model - of which limited review is a component - for the administration of a social insurance program contributes to the difficulties experienced by the VA).

216 VA Claims Processing Task Force, Report to the Secretary of Veterans Affairs, at 9 (Oct. 2001). In 1992, the VA had 531,078 pending claims, while the number was 342,683 claims in 1996. Id. 


\section{STANDARDS-BASED JUDICIAL REVIEW}

55

process a claim. $^{217}$ Moreover, over the last seven years, CAVC has remanded nearly 70 percent of the appeals it has heard, ${ }^{218}$ and the VA takes nearly five times as long to process a remand as an original claim. ${ }^{219}$

Professor James O'Reilly argues the CAVC's Article I status has contributed to the VA's failure to reform itself because the court lacks sufficient independence from the VA. ${ }^{220}$ According to Professor O'Reilly, "[T]he reading of dozens of CAVC decisions convinces the reader that the CAVC does not exhibit the will to compel the VA to deliver timely and accurate service to those who present claims before the CAVC. The CAVC itself seems captive of a dysfunctional system." ${ }^{221} \mathrm{He}$ compares the more favorable record of Article III review of social security cases, discussed previously, and recommends that Congress abolish the CAVC and adopt the Social Security appeals model for VA. ${ }^{222}$

We do not wish to overstate the differences between Social Security and Veterans benefits. Judicial review has not prevented controversies surrounding the Social Security benefit decisions and many claimant advocates remain dissatisfied with the system. Moreover, problems at the VA are attributable to a variety of factors, including inadequate funding and personnel and inherent difficulties in processing claims. ${ }^{223}$ Nevertheless, we concur with Professor O'Reilly that the CAVC's Article I status has contributed to the failure of reform.

It is extraordinary that the CAVC has remanded 70 percent of the disability appeals it has heard. This record may simply reflect the VA's inability to get it right the first time. An examination of these appeals,

${ }^{217}$ Id. at __. The VA can take as long as seven years to resolve a claim. Id.

${ }^{218}$ See United States Court of Appeals for Veterans Claims, Annual Reports (available at www.vetapp.uscourts.gov/AboutCourt/AnnualReport.asp).

219 As of July 2001, the regional offices took at average of 184.2 days to render a decision on an initial claim and an average of 672 days to process a remand from the CAVC or the BVA. This delay has increased since 1995 when the processing time for a remand was 561 days. VA Claims Processing Task Force, supra note _, at _.

${ }^{220}$ O'Reilly, supra note __, at 228; but see Gary O' Connor, Rendering to Caesar: A Response to Professor O'Reilly, 53 ADMIN. L. REV. 343 (2001) (disputing Professor O'Reilly's conclusions).

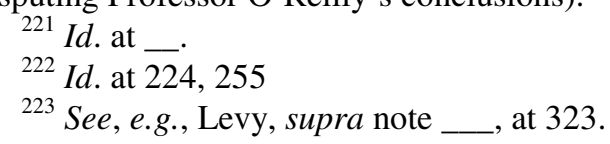


however, also indicates that the CAVC has exhibited excessive tolerance for VA delay and ineptitude by failing to interpret its powers and the VA's mandate in ways that could speed decisionmaking and improve its accuracy. ${ }^{224}$ The CAVC's failure to act forcefully may be the product of any number of causes. When we compare the court's failure to act with the strong and persistent effort of Article III judges to hold SSA accountable in the 1980s, however, we are left with the firm impression that the court's Article I status is a key factor.

The experience with the VA suggests to us the independence of Article III judges can be an important element in establishing meaningful and effective judicial review. The experience with the VA also suggests to us the practical consequences of denying meaningful and independent review. In light of the delays at the VA, it is not at all unusual for a veteran to die before his or her meritorious disability claim is resolved. ${ }^{225}$

\section{CONCLUSION}

The rule of law is central our constitutional order. Its protections should apply broadly to government action, including the allocation of government benefits. Under current doctrine, however, that is not always the case, particularly when it comes to government benefits. Instead, the application of essential rule of law safeguards, including judicial review, is a matter of legislative grace.

In this article, we have attempted to clear away the doctrinal morass that complicates this important area of the law. We have demonstrated that the public rights doctrine should have no bearing on the necessity of judicial review. We have shown that the due process and Article III

${ }^{224}$ See Levy, supra note ___, at 321-22 (discussing failure of the CAVC to scrutinize VA benefit decisions carefully notwithstanding recent legislation designed to encourage a more aggressive posture); James T. O'Reilly, Burying Ceaser: Replacement of the Veterans Appeals Process Is Needed to Provide Fairness to Claimants, 53 Ad. L. Rev. 223 (2001) (explaining ways the CAVC could have, but has not, improved VA decisionmaking); Bill Russo, Ten Years After the Battle for Veterens Judicial Review: An Assessment, Fed. Law., June, 1999, at 29 (same); [check this]); Section of Administrative Law and Regulatory Practice, American Bar Association, Report and Recommendation (date?) (same).

${ }^{225}$ Many claims are made by elderly World War II or Korean veterans in the last few years prior to their deaths. Robin J. Arzt, What Veterans Would Gain From Administrative Procedure Act Adjudications, TOMMY: A LAWYERS GUIDE TO Veterans AFFAIRS, Issue 2, 2002, at 1. 
jurisprudence on the foreclosure of judicial review fails to resolve the critical issue of whether Congress can foreclose nonconstitutional review of agency action, and it offers no coherent explanation of how the foreclosure of judicial review can be reconciled with the rule of law. And we have presented our alternative - a standards-based approach to judicial review.

The standards-based approach offers a coherent account not only of judicial review, but also of due process (as we have argued in a companion article to this one). It is therefore a much more promising approach to the rule of law than either current doctrine or the alternatives that have been suggested in the literature. 